\title{
Legume-Rhizobium Strain Specificity Enhances Nutrition and Nitrogen Fixation in Faba Bean (Vicia faba L.)
}

\author{
Bayou Bunkura Allito ${ }^{1, *}$, Nana Ewusi-Mensah ${ }^{2}$ and Vincent Logah ${ }^{2}$ D \\ 1 Department of Plant and Horticultural Science, Hawassa University College of Agriculture, \\ Hawassa P.O. Box 05, Ethiopia \\ 2 Department of Crop and Soil Sciences, Kwame Nkrumah University of Science and Technology, \\ Kumasi AK-039, Ghana; nanaewusi@yahoo.com (N.E.-M.); vlogah@yahoo.co.uk (V.L.) \\ * Correspondence: bayoubunkura@gmail.com; Tel.: +251-948-050106
}

Received: 6 November 2019; Accepted: 23 December 2019; Published: 11 June 2020 updates

\begin{abstract}
This study reports the effectiveness of some selected rhizobium strains in enhancing nitrogen fixation and nutrient uptake in Vicia faba L. Multi-location field experiments were conducted for two years (2016 and 2017) using a split-plot in randomized complete block design. Treatments comprised six rhizobium strains as the main plot factor and three varieties of Vicia faba as the sub-plot factor. Non-inoculated plants with or without $\mathrm{N}$ fertilizer served as $+\mathrm{N}$ and $-\mathrm{N}$ controls, respectively. Peat carrier-based inoculant of each strain was applied at the rate of $10 \mathrm{~g} \mathrm{~kg}^{-1}$ seed. Data on nodulation were taken at the late-flowering stage, whereas nitrogen and phosphorus concentrations in plant parts were analyzed at physiological maturity. The total nitrogen difference method was employed to quantify nitrogen fixation. Location $\mathrm{x}$ rhizobium strain $\mathrm{x}$ variety interaction had a significant effect on nodule dry weight plant ${ }^{-1}$. Rhizobium strains significantly enhanced nodulation, nitrogen fixation, nutrient uptake and soil nitrogen balance. Inoculation with NSFBR-12 and NSFBR-15 resulted in the highest nitrogen fixed, nutrient uptake and soil nitrogen balance. Vicia faba inoculated with the two top performing strains, NSFBR-12 and NSFBR-15 fixed respectively $87.7 \%$ and $85.5 \%$ of the total nitrogen uptake. Non-inoculated plants fulfilled proportionately more of the total nitrogen uptake through nitrogen derived from the soil rather than fixed nitrogen. Soil available phosphorus and $\mathrm{pH}$ had appreciable influences on nitrogen and phosphorus uptake of inoculated Vicia faba. Inoculation with competitive and effective rhizobium strains can improve soil nitrogen balance, nitrogen fixation and nutrient uptake of Vicia faba.
\end{abstract}

Keywords: inoculation; nodulation; nutrient uptake; rhizobium strain; Vicia faba

\section{Introduction}

Declining soil fertility is one of the major challenges in crop production among smallholder farmers in sub-Saharan Africa [1]. Nitrogen $(\mathrm{N})$ is the most commonly limiting soil nutrient contributing to reduced agricultural yields throughout the region. Unfortunately, resource-poor farmers are unable to afford inorganic fertilizer costs to compensate for the nitrogen deficiency in their farms. In addition, different processes lead to more than $50 \%$ loss of the applied nitrogen fertilizer, which represents a cash loss to farmers and a source of environmental pollution [2]. The increasing cost of inorganic fertilizer and its adverse impacts on the environment have therefore attracted research interest to scout for alternative sources of nitrogen.

Legume-rhizobium symbioses can be an alternative source of available $\mathrm{N}$, which reduces the use of inorganic fertilizer while maintaining crop yield at high levels [3]. Reduction in chemical 
fertilizer utilization, in turn, can decrease cost of production and eliminate its adverse environmental impacts. Fixed nitrogen through legume-rhizobium symbioses is regarded as a renewable source of nitrogen in agriculture since it has a limited probability to leach or volatilize from the system [4]. Effective legume-rhizobium symbioses can enhance nitrogen levels in soil and reduce nitrogen fertilizer requirement for subsequent crops [5].

Faba bean (Vicia faba L.) usually forms effective symbiotic association with Rhizobium leguminosarum symbiovar viciae (Rlv), which is a symbiont specific to the legumes of the tribe vicieae [6,7]. The crop is grown in sub-Saharan Africa where there are wild hosts and numerous compatible rhizobia (Rlv) [7]. Consequently, the roots of non-inoculated plants in the bulk soil are exposed to diverse native rhizobial populations, which vary in nodulation and nitrogen fixation capacity [8,9]. As a result of the wide variation in abundance and effectiveness of natural Rlv populations, attaining the maximum nitrogen fixation of the faba bean is rarely possible unless inoculated [8]. Sánchez-Ca izares et al. [10] demonstrated a wide diversity of plasmids within Rlv species, especially for the symbiotic plasmid, suggesting the need for inoculation with appropriate rhizobial strains for maximizing symbiotic nitrogen fixation [11]. Inoculation can ensure availability of efficient rhizobium strain population in the rhizosphere of the plant and enhances the contribution of host-legume in cropping system.

Inoculation affects microbial populations and community in the rhizosphere [3]. The strain must survive in soil environment and take advantage of ecological niches offered by the roots of the plants [12]. However, poorly-fixing naturally occurring rhizobial strains may strive and gain advantage over an introduced strain $[13,14]$. Rhizobial strain choice, therefore, should include competitiveness in nodulation and adaptation to the prevailing soil environment in addition to effectiveness in nitrogen fixation. Effectiveness, abundance and competitiveness of the rhizobium strain are essential attributes to consider [15]. In order to optimize benefits of symbiotic nitrogen fixation, inoculant strain must be efficient and match the desired faba bean variety in a growing agro-ecological zone. Adaptation of host-specific rhizobial strain to the local environment and soil condition increases the chance for effective nodulation [16]. The aim of this study was therefore to determine the effectiveness of selected faba bean rhizobium strains on nutrient uptake, nitrogen fixation and soil nitrogen balance in southern Ethiopia.

\section{Materials and Methods}

\subsection{Description of Field Experimental Sites}

Four different locations were selected in two major faba bean growing agro-ecologies (cool-humid and cool sub-humid) in southern Ethiopia. Two locations-Hankomolicha and Abala Gase-in cool humid zones, and two locations, Haranfama and Gike Atoye, in cool sub-humid agro-ecological zones were selected for field experiments. The experimental locations in cool humid and cool sub-humid agro-ecological zones received $1472.9 \mathrm{~mm}$ and $1092.5 \mathrm{~mm}$ mean annual rainfall (Table 1), respectively. The distribution of rainfall in both agro-ecologies is bimodal. A minor rainy season occurs from February to April whereas the major rainy season occurs from June to September. In each agro-ecology, experiments were conducted at selected locations during the major rainy season of 2016 and 2017. 
Table 1. Annual average rainfall and the mean maximum and minimum temperatures during the study period and long-term average.

\begin{tabular}{|c|c|c|c|c|c|c|c|}
\hline \multirow{2}{*}{\multicolumn{2}{|c|}{ Year }} & \multicolumn{3}{|c|}{$\begin{array}{c}\text { Cool Humid } \\
\text { (Location: HK and AG) }\end{array}$} & \multicolumn{3}{|c|}{$\begin{array}{c}\text { Cool Sub-Humid } \\
\text { (Location: HR and GA) }\end{array}$} \\
\hline & & $\begin{array}{c}\text { Rainfall } \\
\mathrm{mm}\end{array}$ & $\frac{{ }^{\text {a }} \text { Max. T }}{{ }^{\circ} \mathrm{C}}$ & $\frac{{ }^{b} \text { Min. T }}{{ }^{\circ} \mathrm{C}}$ & $\begin{array}{c}\text { Rainfall } \\
\mathrm{mm}\end{array}$ & $\frac{{ }^{a} \text { Max. T }}{{ }^{\circ} \mathrm{C}}$ & $\frac{{ }^{\mathrm{b}} \text { Min. T }}{{ }^{\circ} \mathrm{C}}$ \\
\hline \multirow{5}{*}{2016} & June & 179.6 & 14.1 & 7.7 & 127.6 & 21.3 & 12.9 \\
\hline & July & 133.5 & 16.4 & 5.6 & 96.8 & 24.3 & 12.5 \\
\hline & August & 182.2 & 16.3 & 6.1 & 191.5 & 22.8 & 11.6 \\
\hline & September & 159.6 & 16.5 & 7.2 & 104.0 & 23.7 & 13.4 \\
\hline & Annual & 1477.6 & 17.1 & 8.1 & 1303.0 & 25.2 & 15.1 \\
\hline \multirow{5}{*}{2017} & June & 62.8 & 17.0 & 9.2 & 35.0 & 25.1 & 15.3 \\
\hline & July & 218.8 & 15.6 & 5.2 & 160.7 & 23.3 & 11.9 \\
\hline & August & 218.8 & 14.1 & 6.5 & 165.7 & 20.9 & 11.3 \\
\hline & September & 206.0 & 14.0 & 7.8 & 204.1 & 19.1 & 10.9 \\
\hline & Annual & 1590.6 & 17.4 & 9.3 & 1199.2 & 24.5 & 14.4 \\
\hline $\begin{array}{c}10 \text { years } \\
(2008-2017)\end{array}$ & $\begin{array}{l}\text { Annual } \\
\text { Average }\end{array}$ & 1472.9 & 15.4 & 7.1 & 1092.5 & 22.4 & 11.7 \\
\hline
\end{tabular}

${ }^{a}$ Maximum temperature; ${ }^{b}$ Minimum temperature; $\mathrm{HM}=$ Hankomolicha; AG = Abala Gase; HR = Haranfama; $\mathrm{GA}=$ Gike Atoye.

\subsection{Soil Sampling and Analyses}

Pre-sowing soil samples were collected from each location. Samples were cored to a depth of $20 \mathrm{~cm}$ from 20 random spots of the entire experimental field and composited for determination of soil physico-chemical properties (Table 2). Determination of soil particle size distribution was carried out by the Bouyoucos hydrometer method [17]. Bulk density was determined using the core sampling method as described by Black and Hartge [18]. The soil $\mathrm{pH}$ was determined in 1:2 soil to water ratio [19] using a $\mathrm{pH}$ meter. Exchangeable acidity was determined by extracting the soil samples with $1.0 \mathrm{~N} \mathrm{KCl}$ solution and titrating with sodium hydroxide [20].

Table 2. Physico-chemical properties of surface soils $(0-20 \mathrm{~cm})$ at the study locations.

\begin{tabular}{|c|c|c|c|c|}
\hline \multirow{2}{*}{ Soil Paramete } & \multicolumn{4}{|c|}{ Study Locations } \\
\hline & Hankomolicha & Abala Gase & Haramfama & Gike Atoye \\
\hline pH (1:2; Soil & 6.57 & 5.37 & 6.02 & 5.60 \\
\hline Available P (m & 12.60 & 5.70 & 8.40 & 6.03 \\
\hline Total nitroge & 0.17 & 0.17 & 0.16 & 0.22 \\
\hline Organic carb & 2.06 & 2.22 & 1.75 & 2.34 \\
\hline Organic matt & 3.55 & 3.83 & 3.02 & 4.03 \\
\hline $\mathrm{C}: \mathrm{N}$ rati & 12.10 & 13.10 & 11.30 & 10.80 \\
\hline CEC (meq 10 & 29.40 & 27.56 & 22.60 & 32.81 \\
\hline & 2.11 & 0.93 & 0.95 & 0.83 \\
\hline Exchangeable bases & 3.14 & 0.75 & 2.36 & 1.25 \\
\hline$\left(\mathrm{cmol}_{(+)} \mathrm{kg}^{-1}\right)$ & 13.40 & 15.09 & 12.60 & 17.73 \\
\hline & 7.22 & 5.38 & 6.44 & 5.20 \\
\hline Exc. acidity (cmc & 0.40 & 0.48 & 0.12 & 0.52 \\
\hline Bulk density ( & 1.24 & 1.21 & 1.35 & 1.25 \\
\hline Textural cl & Clay & Clay loam & Loam & Clay \\
\hline
\end{tabular}

Exchangeable bases and cation exchange capacity (CEC) of the soils were determined using a $1.0 \mathrm{~N}$ ammonium acetate ( $\mathrm{pH}$ 7) method, whereas exchangeable $\mathrm{Ca}, \mathrm{Mg}, \mathrm{Na}$ and $\mathrm{K}$ in the extract were measured using an atomic absorption spectrophotometer [21]. Organic carbon was determined following the wet oxidation method [22] and total nitrogen by the macro-Kjeldahl method as described 
by Bremner and Mulvaney [23]. Soil available phosphorus was analyzed using a sodium carbonate extraction solution ( $\mathrm{pH}$ 8.5) method with the amount of $\mathrm{P}$ measured by an atomic absorption spectrophotometer as described by Olsen et al. [24].

\subsection{Source of Strains and Seeds}

Six rhizobial strains (NSFBR-12, NSFBR-15, NSFBR-20, HUFBR-17, TAL_1035 and EAL-110), originally collected by Haremaya University, Holleta Agricultural Research Center and National Soil Laboratory (NSL) in Ethiopia, were used for the study. The inoculum was used at the concentration of approximately $10^{9}$ cells $\mathrm{g}^{-1}$ in a peat carrier. The purity of strain cultures was assessed in the Soil Microbiology Laboratory at Holleta Agricultural Research Center. The sterility of the carrier was checked before mixing with the rhizobial culture. Seeds of three nationally registered faba bean varieties (Dosha (COLL 155/00-3), Moti (EH 95078-6), Gora (EKO1024-1-2) and non-nodulating chickpea (Cicer arietinum) (cultivar PM233) were collected from the Holleta Agricultural Research Center for the study.

\subsection{Treatments and Experimental Design}

A split-plot in a randomized complete block design was used with four replicates nested at four different locations. Main plot treatments consisted of six rhizobium strains. Non-inoculated plants supplied with and without $\mathrm{N}$ fertilizer served as $+\mathrm{N}$ and $-\mathrm{N}$ controls, respectively. Sub-plot treatments were three faba bean varieties.

Land preparation was done following conventional practices to make the field suitable for planting. Each variety was planted in 10 rows of $4 \mathrm{~m}$ length per main plot. The inter-row and intra-row spacing was maintained at $40 \mathrm{~cm}$ and $10 \mathrm{~cm}$, respectively. Spacing between major plots and blocks were $1 \mathrm{~m}$ and $1.5 \mathrm{~m}$, respectively. Peat carrier-based inoculant of each strain was applied at the rate of $10 \mathrm{~g} \mathrm{~kg}^{-1}$ seed [25] before sowing.

Two seeds were sown per hill at a depth of about $4 \mathrm{~cm}$ and the seedlings were thinned to one per hill one week after germination. Phosphorus was applied to all plots in the form of triple-superphosphate at the recommended rate of $46 \mathrm{~kg} \mathrm{P}_{2} \mathrm{O}_{5}$ at planting. Nitrogen fertilizer was applied two times in equal split doses to non-inoculated $+\mathrm{N}$ control treatment, at planting and six weeks after sowing at a recommended rate of $46 \mathrm{~kg} \mathrm{~N} \mathrm{ha}^{-1}$. Non-nodulating chickpea cultivar (PM233) was used as a reference crop and seeded in a plot adjacent to each replication.

\subsection{Nodulation Assessment}

At late flowering, six plants from the middle rows of each plot were randomly selected and uprooted with a ball of surrounding soil using a spade so as to obtain intact roots and nodules. The nodulation assessment included all roots in $30 \mathrm{~cm}$ soil depth. The adhering soil on the roots was carefully removed and the roots with intact nodules were washed gently using tap water on a metal mesh sieve. The nodules on the roots were picked, pooled and oven dried at $70{ }^{\circ} \mathrm{C}$ for $48 \mathrm{~h}$ and the average nodule weight plant $^{-1}$ was estimated.

\subsection{Determination of Nitrogen and Phosphorus Uptake}

At physiological maturity, 10 representative plants per plot were randomly selected and uprooted using a spade. Shoots were cut from roots at the collar and pods were removed, counted and placed in pre-marked paper bags. The straws (dry shoots) were cut into small pieces and also placed in pre-marked paper bags. The adhering soil on roots was removed by washing the roots under tap water. The roots were sun-dried and placed in pre-labeled paper bags.

The pod samples were sun-dried and threshed manually. The grain and husk were transferred into separate pre-labeled paper bags. The root, straw, grain and husk samples were oven-dried at $70^{\circ} \mathrm{C}$ for $72 \mathrm{~h}$ and weighed. Each plant material was finely ground and $20 \mathrm{~g}$ sub-samples were transferred into pre-marked glass containers. The composite samples of root, haulm (husk + straw) and grain for 
each treatment and reference plant were chemically analyzed to determine nitrogen and phosphorus concentrations. The nitrogen contents in the root, haulm and grain sub-samples were determined using the modified macro-Kjeldahl method as per the procedure suggested by AOAC [26]. Root yield was estimated using shoot to root ratio data measured at late flowering. Nitrogen uptake in the root, haulm and grain were determined quantitatively as follows:

$$
\begin{gathered}
\text { Haulm nitrogen uptake }\left(\mathrm{kg} \mathrm{ha}^{-1}\right)=\frac{\text { Haulm N conc. }\left(\frac{\mathrm{g}}{\mathrm{kg}}\right) \times \text { Haulm dry weight }\left(\frac{\mathrm{kg}}{\mathrm{ha}}\right)}{1000} \\
\text { Grain nitrogen uptake }\left(\mathrm{kg} \mathrm{ha}^{-1}\right)=\frac{\text { Grain N conc. }\left(\frac{\mathrm{g}}{\mathrm{kg}}\right) \times \text { Grain dry yield }\left(\frac{\mathrm{kg}}{\mathrm{ha}}\right)}{1000} \\
\text { Root nitrogen uptake }\left(\mathrm{kg} \mathrm{ha}^{-1}\right)=\frac{\text { Root } \mathrm{N} \text { conc. }\left(\frac{\mathrm{g}}{\mathrm{kg}}\right) \times \text { Estimated root dry yield }\left(\frac{\mathrm{kg}}{\mathrm{ha}}\right)}{1000} \\
\text { Total } \mathrm{N} \text { uptake }=\text { Root } \mathrm{N} \text { uptake }+ \text { Haulm } \mathrm{N} \text { uptake }+ \text { Grain } \mathrm{N} \text { uptake }
\end{gathered}
$$

Haulm, root and grain nutrient uptake were calculated from nutrient concentrations and the final dry matter yields of respective plant parts. Phosphorus in the root, haulm and grain sub-samples were also determined using the meta-vanadate method as described in NSL [27]. Likewise, total phosphorus uptake was calculated as the sum of phosphorus uptake in root, haulm and grain of faba bean plants.

\subsection{Determination of Nitrogen Fixation}

Total soil nitrogen contents after harvest of each treatment and reference crop plots were analyzed according to procedure described by Bremner and Mulvaney [23]. The quantity of symbiotically fixed nitrogen was estimated using the extended total nitrogen difference method as suggested by Unkovich et al. [28]. The procedure comprises the differences in total uptake of nitrogen and the depletion in the soil $(0-30 \mathrm{~cm})$ between fixing faba bean and the non-nodulating reference chickpea (cultivar PM233) as follows:

$$
\mathrm{Q}(\mathrm{Ndfa})=[\mathrm{N} \text { uptake }(\mathrm{leg})-\mathrm{N} \text { uptake }(\text { ref })]+[\mathrm{N} \text { soil }(\mathrm{leg})-\mathrm{N} \text { soil }(\text { ref })]
$$

where: $\mathrm{Q}(\mathrm{Ndfa})=$ quantity of nitrogen derived from atmosphere via fixation, $\mathrm{N}$ uptake $(\mathrm{leg})=$ nitrogen uptake of fixing legume crop, $\mathrm{N}$ uptake (ref) = nitrogen uptake of non-fixing reference crop, $\mathrm{N}$ soil $($ leg) $=$ post-harvest soil nitrogen content under fixing legume crop and $\mathrm{N}$ soil (ref) = post-harvest soil nitrogen content under non-fixing reference crop.

\subsection{Determination of Soil Nitrogen Balance}

The net nitrogen contribution to the soil nitrogen balance (Nba) was calculated by subtracting nitrogen output from nitrogen input in two scenarios, using Equations (1) and (2) below as described by Kermah et al. [29].

Scenario 1 (only grain exported):

$$
\mathrm{Nba}_{1}=(\mathrm{Nfer}+\mathrm{Nfix})-\mathrm{Ng}
$$

Scenario 2 (grain + haulm exported):

$$
\mathrm{Nba}_{2}=(\mathrm{Nfer}+\mathrm{Nfix})-\mathrm{Ng}-\mathrm{Nh}
$$

where: $\mathrm{Nfer}=$ Applied $\mathrm{N}$ fertilizer $\left(\mathrm{kg} \mathrm{ha}^{-1}\right) ; \mathrm{Nfix}=\mathrm{N}_{2}$ fixed; $\mathrm{Ng}=\mathrm{N}$ removed by faba bean grain and $\mathrm{Nh}=\mathrm{N}$ removed by faba bean haulm. 


\subsection{Statistical Analysis}

The data collected were subjected to Analysis of Variance using SAS [30] computer software (SAS Institute Inc. Cary, N.C., USA). Combined analysis of variance was done to assess significance among locations, rhizobium strains, faba bean varieties and interactions among these three factors (location, strain and variety) for all measured parameters. Mean separation and comparison were carried out using Duncan's Multiple Range Test. A Pearson correlation test was conducted to determine association among treatment means using a $p \leq 0.05$ probability level.

\section{Results}

\subsection{Rhizobium Strains Inoculation Effect on Nodulation}

Table 3 shows increased nodule dry weight (NDW) plant $^{-1}$ following inoculation relative to the non-inoculated $-\mathrm{N}$ control treatments across the study locations. Analysis of variance across the study locations revealed that location $\times$ rhizobium strain $\times$ variety $(L \times R \times V)$ interactions had a significant effect on nodule dry weight plant ${ }^{-1}$. Inoculation of NSFBR-15 to variety Dosha and TAL_1035 to variety Gora resulted in the first $\left(463.9 \mathrm{mg} \mathrm{plant}^{-1}\right)$ and the second (414.3 $\left.\mathrm{mg} \mathrm{plant}^{-1}\right)$ highest nodule dry weight plant $^{-1}$, respectively at Abala Gase (Table 3). Variety Gora inoculated with strain TAL_1035 produced the highest nodule dry weight plant $^{-1}$ at all experimental sites except at Abala Gase where variety Dosha inoculated with strain NSFBR-15 produced the highest nodule dry weight plant ${ }^{-1}$. The lowest nodule dry weight plant ${ }^{-1}\left(100.1 \mathrm{mg} \mathrm{plant}^{-1}\right)$ was observed with non-inoculated $-\mathrm{N}$ control of variety Moti at Abala Gase. 
Table 3. Rhizobium strain and faba bean variety interaction effects on nodule dry weight at the study locations.

\begin{tabular}{|c|c|c|c|c|c|c|c|c|c|c|c|c|}
\hline \multirow{3}{*}{ Treatments } & \multicolumn{3}{|c|}{ Hankomolicha } & \multicolumn{3}{|c|}{ Haranfama } & \multicolumn{3}{|c|}{ Abala Gase } & \multicolumn{3}{|c|}{ Gike Atoye } \\
\hline & Moti & Dosha & Gora & Moti & Dosha & Gora & Moti & Dosha & Gora & Moti & Dosha & Gora \\
\hline & \multicolumn{3}{|c|}{ (mg Plant $^{-1}$ ) } & \multicolumn{3}{|c|}{$\left(\right.$ mg Plant $^{-1}$ ) } & \multicolumn{3}{|c|}{$\left(\mathrm{mg} \mathrm{Plant}^{-1}\right)$} & \multicolumn{3}{|c|}{$\left(\mathrm{mg} \mathrm{Plant}^{-1}\right)$} \\
\hline TAL_1035 & $247.5^{b}$ & $260.3^{a}$ & $295.8^{a}$ & $211.3^{a}$ & $213.3^{a}$ & $261.3^{a}$ & $249.6^{b}$ & $271.8^{b c}$ & $414.3^{\mathrm{a}}$ & $209.5^{d}$ & $219.2^{b}$ & $370.7^{\mathrm{a}}$ \\
\hline NSFBR-15 & $275.0^{\mathrm{a}}$ & $258.0^{\mathrm{a}}$ & $239.0^{\mathrm{b}}$ & $212.5^{\mathrm{a}}$ & $226.5^{\mathrm{a}}$ & $240.3^{b}$ & $203.5^{c}$ & $463.9^{a}$ & $286.7^{b}$ & $258.0^{\mathrm{ab}}$ & $174.0^{\mathrm{c}}$ & $346.9^{\mathrm{a}}$ \\
\hline HUFBR-17 & $216.3^{c}$ & $235.8^{b}$ & $205.5^{c}$ & $198.5^{a b}$ & $163.3^{\mathrm{cd}}$ & $167.8^{\mathrm{d}}$ & $163.5^{d}$ & $155.7^{\mathrm{e}}$ & $151.0^{\mathrm{e}}$ & $232.4 \mathrm{bcd}$ & $184.0^{\mathrm{c}}$ & $118.2^{\mathrm{e}}$ \\
\hline NSFBR-12 & $228.8^{b c}$ & $224.5^{b}$ & $239.5^{b}$ & $207.3^{a b}$ & $192.0^{\mathrm{b}}$ & $216.8^{c}$ & $346.7^{a}$ & $248.8^{c}$ & $234.3^{\mathrm{cd}}$ & $278.9^{a}$ & $272.7^{\mathrm{a}}$ & $284.3^{b}$ \\
\hline EAL-110 & $236.0^{b c}$ & $174.8^{\mathrm{c}}$ & $193.5^{\mathrm{cd}}$ & $176.0^{\mathrm{cd}}$ & $181.3^{b c}$ & $168.8^{\mathrm{d}}$ & $228.3^{b c}$ & $201.3^{d}$ & $254.5^{b c}$ & $220.3^{c d}$ & $144.1^{\text {de }}$ & $252.2^{\mathrm{c}}$ \\
\hline NSFBR-20 & $155.5^{\mathrm{d}}$ & $173.8^{\mathrm{c}}$ & $177.8^{\mathrm{d}}$ & $188.5^{b c}$ & $164.0^{\mathrm{cd}}$ & 153.0 de & $209.1^{\mathrm{c}}$ & $317.3^{b}$ & $201.5^{\mathrm{d}}$ & $245.7^{b c}$ & $230.7^{b}$ & $188.5^{\mathrm{d}}$ \\
\hline$+\mathrm{N}$ & $112.3^{\mathrm{e}}$ & $106.0^{\mathrm{d}}$ & $111.5^{\mathrm{e}}$ & $148.5^{\mathrm{e}}$ & $156.8^{d}$ & 139.8 ef & $154.6^{d}$ & $135.1^{\mathrm{e}}$ & $120.5^{\text {ef }}$ & $182.4^{\mathrm{e}}$ & $121.9^{\mathrm{e}}$ & $299.0^{b}$ \\
\hline$-\mathrm{N}$ & $122.3^{\mathrm{e}}$ & $154.5^{\mathrm{c}}$ & $175.3^{\mathrm{d}}$ & $162.8^{\mathrm{de}}$ & $182.3^{b c}$ & $131.5^{f}$ & $100.1^{\mathrm{e}}$ & $129.3^{e}$ & $105.3^{f}$ & $147.2^{\mathrm{f}}$ & $169.5^{\mathrm{cd}}$ & $113.9^{\mathrm{e}}$ \\
\hline$C V(\%)$ & \multicolumn{3}{|c|}{8.4} & \multicolumn{3}{|c|}{8.2} & \multicolumn{3}{|c|}{12.4} & \multicolumn{3}{|c|}{11.0} \\
\hline
\end{tabular}

Mean values in the same column with different letter(s) are significantly different at a $p \leq 0.05$. 


\subsection{Effect of Inoculation on Nutrient Concentration and Uptake}

Rhizobium strain inoculation significantly $(p \leq 0.05)$ enhanced grain nitrogen as well as root and grain phosphorus concentrations of faba bean (Table 4). Grain nitrogen concentration varied from $1.64 \%$ to $2.01 \%$ whereas grain nitrogen concentration varied from $3.82 \%$ to $4.51 \%$ (Table 4 ). Rhizobium strain NSFBR-20 inoculation resulted in the highest grain nitrogen concentration (4.51\%) followed by HUFBR-17 (4.49\%) while the highest grain phosphorus was observed with TAL_1035 (1.32\%) followed by NSFBR-12 (1.31\%) inoculation (Table 4$)$. Grain nitrogen concentration was relatively lower for the rhizobium strains TAL_1035 and NSFBR-15 (Table 4). However, inoculation of faba bean with TAL_1035, NSFBR-15 and NSFBR-12 resulted in significantly $(p \leq 0.05)$ higher grain phosphorus concentration among the treatments including $-\mathrm{N}$ control.

Table 4. Root, haulm and grain nitrogen and phosphorus concentrations in faba bean inoculated with different rhizobium strains.

\begin{tabular}{ccccccc}
\hline \multirow{2}{*}{ Treatments } & \multicolumn{3}{c}{ N Concentration (\%) } & \multicolumn{3}{c}{ P Concentration (\%) } \\
\cline { 2 - 7 } & Root & Haulm & Grain & Root & Haulm & Grain \\
\hline TAL_1035 & $1.50^{\mathrm{a}}$ & $1.68^{\mathrm{a}}$ & $4.06^{\mathrm{bc}}$ & $0.34^{\mathrm{ab}}$ & $0.23^{\mathrm{a}}$ & $1.32^{\mathrm{a}}$ \\
NSFBR-15 & $1.37^{\mathrm{a}}$ & $1.64^{\mathrm{a}}$ & $4.02^{\mathrm{bc}}$ & $0.35^{\mathrm{ab}}$ & $0.25^{\mathrm{a}}$ & $1.28^{\mathrm{a}}$ \\
HUFBR-17 & $1.44^{\mathrm{a}}$ & $2.01^{\mathrm{a}}$ & $4.49^{\mathrm{a}}$ & $0.31^{\mathrm{b}}$ & $0.26^{\mathrm{a}}$ & $1.24^{\mathrm{ab}}$ \\
NSFBR-12 & $1.52^{\mathrm{a}}$ & $1.75^{\mathrm{a}}$ & $4.15^{\mathrm{abc}}$ & $0.35^{\mathrm{ab}}$ & $0.25^{\mathrm{a}}$ & $1.31^{\mathrm{a}}$ \\
EAL-110 & $1.38^{\mathrm{a}}$ & $1.89^{\mathrm{a}}$ & $4.36^{\mathrm{ab}}$ & $0.34^{\mathrm{ab}}$ & $0.26^{\mathrm{a}}$ & $1.13^{\mathrm{bcd}}$ \\
NSFBR-20 & $1.38^{\mathrm{a}}$ & $1.94^{\mathrm{a}}$ & $4.51^{\mathrm{a}}$ & $0.33^{\mathrm{ab}}$ & $0.28^{\mathrm{a}}$ & $1.20^{\mathrm{abc}}$ \\
+N & $1.43^{\mathrm{a}}$ & $1.83^{\mathrm{a}}$ & $3.82^{\mathrm{c}}$ & $0.38^{\mathrm{a}}$ & $0.30^{\mathrm{a}}$ & $1.04^{\mathrm{d}}$ \\
-N & $1.45^{\mathrm{a}}$ & $1.81^{\mathrm{a}}$ & $4.19^{\mathrm{abc}}$ & $0.30^{\mathrm{b}}$ & $0.27^{\mathrm{a}}$ & $1.10^{\mathrm{cd}}$ \\
CV $(\%)$ & $\mathbf{1 8 . 5}$ & $\mathbf{1 7 . 4}$ & $\mathbf{1 0 . 3}$ & $\mathbf{1 6 . 5}$ & $\mathbf{1 9 . 8}^{\mathbf{1 9}}$ & $\mathbf{1 2 . 2}$ \\
\hline
\end{tabular}

Grain, haulm, root and total nitrogen uptake of faba bean were enhanced by rhizobium strain inoculation and nitrogen fertilizer application (Table 5). No significant differences were observed among the faba bean varieties and strain $\times$ variety interaction on nitrogen uptake. Grain nitrogen uptake ranged between 80.1 and $124.5 \mathrm{~kg} \mathrm{~N} \mathrm{ha}^{-1}$ (Table 5). Inoculation with NSFBR-15, TAL_1035 and NSFBR-12 showed significantly $(p \leq 0.05)$ higher grain nitrogen uptake than HUFBR-17, EAL-110 and NSFBR-20 and non-inoculated $-\mathrm{N}$ control. Haulm nitrogen uptake ranged from $94.4 \mathrm{~kg} \mathrm{~N} \mathrm{ha}^{-1}$, which was obtained with non-inoculated $-\mathrm{N}$ control to $156.6 \mathrm{~kg} \mathrm{~N}$ ha-1 that was obtained with NSFBR-15 (Table 5). The highest haulm nitrogen uptake (156.6 $\mathrm{kg} \mathrm{N} \mathrm{ha}^{-1}$ ) was obtained with NSFBR-15 inoculation followed by TAL_1035 and NSFBR-12 with haulm nitrogen uptake of 155.3 and $152.8 \mathrm{~kg} \mathrm{~N} \mathrm{ha}^{-1}$, respectively. Inoculation with NSFBR-15 and TAL_1035 also resulted in the highest root nitrogen uptake of faba bean.

Total nitrogen uptake ranged from $194.7 \mathrm{~kg} \mathrm{~N} \mathrm{ha}^{-1}$ to $309.6 \mathrm{~kg} \mathrm{~N} \mathrm{ha}^{-1}$ (Table 5). Rhizobium strain NSFBR-15 inoculation resulted in the highest total nitrogen uptake $\left(309.6 \mathrm{~kg} \mathrm{~N} \mathrm{ha}^{-1}\right)$ followed by TAL_1035 and NSFBR-12 which resulted in the second and third highest nitrogen uptake of $305.6 \mathrm{~kg} \mathrm{~N} \mathrm{ha}^{-1}$ and $296.5 \mathrm{~kg} \mathrm{~N} \mathrm{ha}^{-1}$, respectively. Inoculation with NSFBR-15, TAL_1035 and NSFBR-12 increased nitrogen uptake by $59.0 \%, 57.0 \%$ and $52.3 \%$, respectively but nitrogen fertilizer application ( $46 \mathrm{~kg} \mathrm{~N} \mathrm{ha}^{-1}$ ) enhanced nitrogen uptake by $45.8 \%$ over non-inoculated $-\mathrm{N}$ control faba bean plants (Figure 1). Rhizobium strains HUFBR-17, EAL-110 and NSFBR-20 inoculation resulted in higher total nitrogen uptake than the non-inoculated $-\mathrm{N}$ control treatment but lower than that of NSFBR-15, TAL_1035 and NSFBR-12. 
Table 5. Root, haulm and grain nitrogen and phosphorus uptakes in faba bean inoculated with different rhizobium strains.

\begin{tabular}{|c|c|c|c|c|c|c|c|c|}
\hline \multirow{2}{*}{ Treatments } & \multicolumn{4}{|c|}{ Nitrogen Uptake (kg N ha ${ }^{-1}$ ) } & \multicolumn{4}{|c|}{ Phosphorus Uptake (kg P ha-1) } \\
\hline & Root & Haulm & Grain & Total & Root & Shoot & Grain & Total \\
\hline TAL_1035 & $28.6^{a}$ & $155.3^{a}$ & $121.7^{\mathrm{a}}$ & $305.6^{a}$ & $6.4^{\mathrm{abc}}$ & $21.7^{\mathrm{ab}}$ & $39.9^{a}$ & $68.0^{\mathrm{ab}}$ \\
\hline NSFBR-15 & $28.5^{\mathrm{a}}$ & $156.6^{\mathrm{a}}$ & $124.5^{\mathrm{a}}$ & $309.6^{a}$ & $7.4^{\mathrm{a}}$ & $24.5^{\mathrm{a}}$ & $39.9^{\mathrm{a}}$ & $71.8^{a}$ \\
\hline HUFBR-17 & $25.8^{\mathrm{ab}}$ & $133.5^{\mathrm{ab}}$ & $101.7^{\mathrm{c}}$ & $261.1^{b}$ & $5.4^{\mathrm{c}}$ & $16.5^{\mathrm{cd}}$ & $28.0^{\mathrm{b}}$ & $49.9^{d}$ \\
\hline NSFBR-12 & $27.2^{\mathrm{ab}}$ & $152.8^{\mathrm{a}}$ & $116.5^{\mathrm{ab}}$ & $296.5^{a}$ & $6.2^{b c}$ & $21.5^{\mathrm{ab}}$ & $36.7^{\mathrm{a}}$ & $64.4^{b c}$ \\
\hline EAL-110 & $26.8^{\mathrm{ab}}$ & $129.4^{b}$ & $103.8^{c}$ & $260.0^{b}$ & $6.7^{\mathrm{ab}}$ & $18.0^{\mathrm{bc}}$ & $27.1^{\mathrm{b}}$ & $51.8^{\mathrm{d}}$ \\
\hline NSFBR-20 & $25.5^{\mathrm{ab}}$ & $130.1^{b}$ & $102.3^{c}$ & $257.9^{b}$ & $6.0^{b c}$ & $18.4^{b c}$ & $27.3^{b}$ & $51.7^{\mathrm{d}}$ \\
\hline$+\mathrm{N}$ & $23.4^{b c}$ & $153.5^{a}$ & $106.8^{b c}$ & $283.8^{\mathrm{ab}}$ & $6.4^{\mathrm{abc}}$ & $24.8^{a}$ & $29.2^{b}$ & $60.4^{\mathrm{c}}$ \\
\hline$-\mathbf{N}$ & $20.3^{c}$ & $94.4^{\mathrm{c}}$ & $80.1^{\mathrm{d}}$ & $194.7^{\mathrm{c}}$ & $4.0^{\mathrm{d}}$ & $13.3^{\mathrm{d}}$ & $21.2^{\mathrm{c}}$ & $38.5^{\mathrm{e}}$ \\
\hline$C V(\%)$ & 18.2 & 18.8 & 13.3 & 14.1 & 19.5 & 22.2 & 16.1 & 14.7 \\
\hline
\end{tabular}

Mean values in the same column with different letter(s) are significantly different at $p \leq 0.05$.

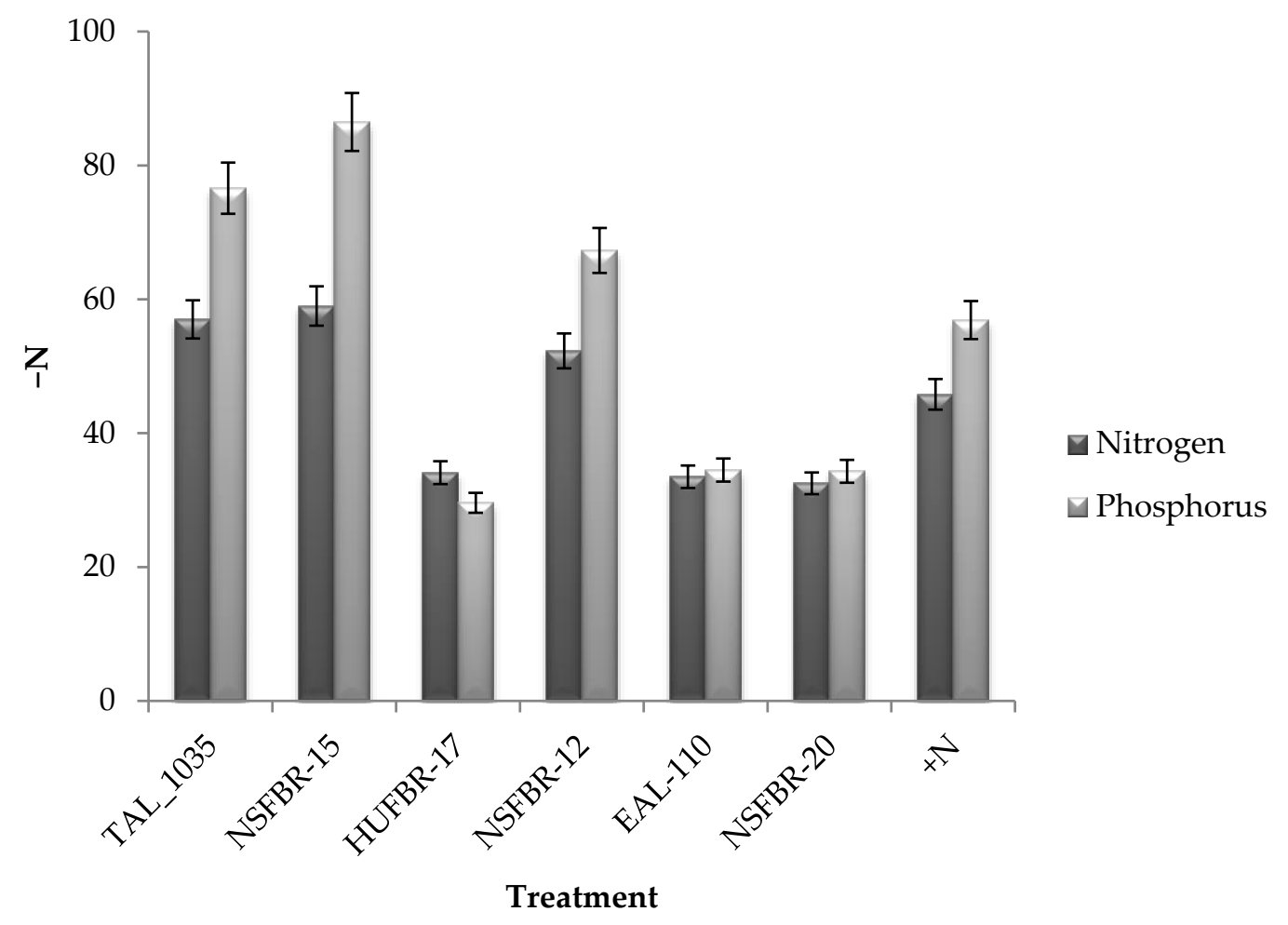

Figure 1. Percentage increase in total nitrogen and phosphorus uptake in inoculated plants over non-inoculated $-\mathrm{N}$ control.

Nitrogen uptake of faba bean was significantly $(p \leq 0.05)$ influenced by differences in study locations (Figure 2). All rhizobium strains inoculation and non-inoculated $+\mathrm{N}$ and $-\mathrm{N}$ controls resulted in the highest nitrogen uptake at Hankomolicha as compared to respective treatments in all other study locations. The highest mean nitrogen uptake recorded at Hankomolicha $\left(330 \mathrm{~kg} \mathrm{~N} \mathrm{ha}^{-1}\right)$ was followed by that of Gike-Atoye (269.8 $\mathrm{kg} \mathrm{N} \mathrm{ha}^{-1}$ ) (Figure 2). 


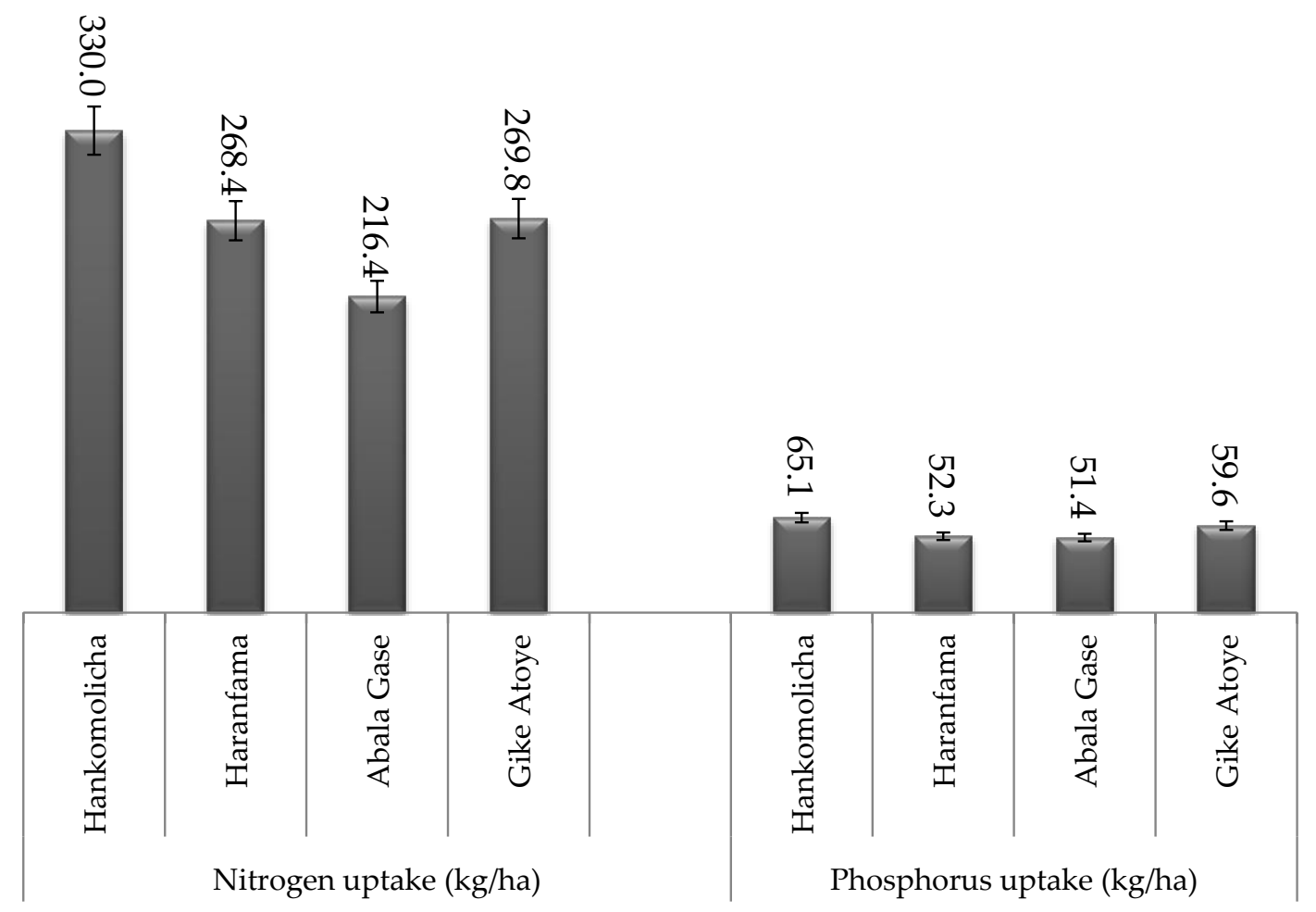

Figure 2. Nitrogen and phosphorus uptake of faba bean at the study locations.

Inoculation and nitrogen fertilizer application significantly $(p \leq 0.05)$ increased phosphorus uptake of faba bean plants (Table 5). However, faba bean varieties and strain $\times$ variety interaction had no significant effects on phosphorus uptake. Rhizobium strains TAL_1035, NSFBR-15 and NSFBR-12 inoculation resulted in higher grain phosphorus uptakes as compared with other rhizobium strains inoculation and the control plants. On the other hand, nitrogen fertilizer application resulted in the highest shoot phosphorus uptake $\left(24.8 \mathrm{~kg} \mathrm{~N} \mathrm{ha}^{-1}\right)$, which was statistically equal to NSFBR-15 inoculation (24.5 $\mathrm{kg} \mathrm{N} \mathrm{ha}^{-1}$ ) (Table 5).

Rhizobium strain NSFBR-15 inoculation produced the highest total phosphorus uptake $\left(71.8 \mathrm{~kg} \mathrm{P} \mathrm{ha}^{-1}\right)$ followed by TAL_1035 $\left(68.0 \mathrm{~kg} \mathrm{P} \mathrm{ha}^{-1}\right)$ whereas non-inoculated -N control accumulated the least phosphorus (38.5 $\mathrm{kg} \mathrm{P} \mathrm{ha}^{-1}$ ) among the treatments (Table 5). Inoculation with NSFBR-15, TAL_1035 and NSFBR-12 resulted in $86.5 \%, 76.6 \%$ and $67.3 \%$ increment in total phosphorus uptake over non-inoculated $-\mathrm{N}$ control, respectively (Figure 1). However, nitrogen fertilizer application resulted in $56.9 \%$ phosphorus uptake increment over $-\mathrm{N}$ control plants. Phosphorus uptake also varied significantly $(p \leq 0.05)$ among the study locations. The highest total phosphorus uptake was observed at Hankomolicha (65.1 $\left.\mathrm{kg} \mathrm{P} \mathrm{ha}^{-1}\right)$ whereas the least phosphorus uptake $\left(51.4 \mathrm{~kg} \mathrm{P} \mathrm{ha}^{-1}\right)$ was observed at Abala Gase (Figure 2).

\subsection{Inoculation Effects on Nitrogen Fixation}

Rhizobium strain inoculation led to significant $(p<0.05)$ differences in nitrogen fixation of faba bean over the control treatments. Rhizobium strain NSFBR-15 inoculation led to the highest amount of nitrogen fixed (264.7 kg ha-1) followed by NSFBR-12 inoculation $\left(260.1 \mathrm{~kg} \mathrm{ha}^{-1}\right)$ while the least was observed with non-inoculated $-\mathrm{N}$ control $\left(95.6 \mathrm{~kg} \mathrm{~N} \mathrm{ha}^{-1}\right)$. No significant differences in nitrogen fixation were observed among the faba bean varieties and strain $\times$ variety interaction. Inoculation with NSFBR-15, NSFBR-12 and TAL_1035 showed increments of $176.9 \%, 172.1 \%$ and $148.1 \%$ of fixed N, respectively over the non-inoculated $-\mathrm{N}$ control (Figure 3). Non-inoculated $+\mathrm{N}$ control faba bean plants fixed significantly higher nitrogen $\left(167 \mathrm{~kg} \mathrm{~N} \mathrm{ha}^{-1}\right)$ than non-inoculated $-\mathrm{N}$ control $\left(95.6 \mathrm{~kg} \mathrm{ha}^{-1}\right)$. 


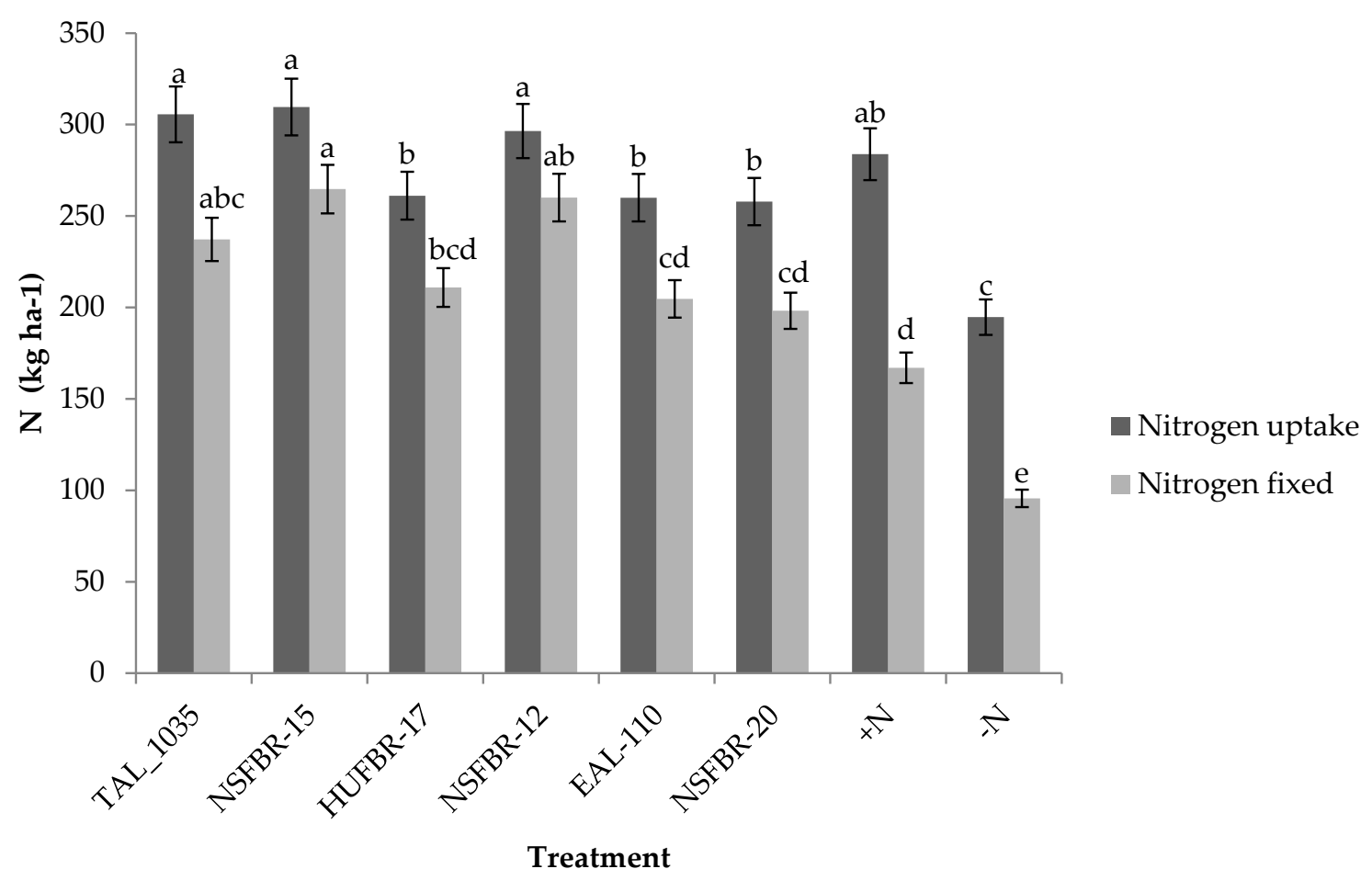

Figure 3. Total nitrogen uptake and nitrogen fixed by faba bean inoculated with different rhizobium strains.

The proportion of biologically fixed nitrogen and nitrogen uptake increased with rhizobium strain inoculation (Figure 3). Faba bean plants inoculated with NSFBR-12 and NSFBR-15 fulfilled 87.7 and $85.5 \%$ of nitrogen uptake through nitrogen fixation, respectively. In contrast, non-inoculated $-\mathrm{N}$ faba bean plants fulfilled more proportion of nitrogen uptake through nitrogen derived from the soil than fixed nitrogen.

\subsection{Effects of Inoculation on Soil Nitrogen Balance}

Soil nitrogen balances ranged from15.5 to $143.6 \mathrm{~kg} \mathrm{~N} \mathrm{ha}^{-1}$ when only grain was removed (Figure 4). Inoculation of rhizobium strains increased soil nitrogen balance over non-inoculated $-\mathrm{N}$ control. Rhizobium strain NSFBR-12 resulted in the highest soil nitrogen balance $\left(143.6 \mathrm{~kg} \mathrm{~N} \mathrm{ha}^{-1}\right)$ followed by NSFBR-15 (140.2 $\mathrm{kg} \mathrm{N} \mathrm{ha}^{-1}$ ) when only grains were exported.

Both rhizobium strain inoculation and nitrogen fertilizer application to faba bean consistently led to soil nitrogen mining when both grain and haulm were removed. Non-inoculated $-\mathrm{N}$ and $+\mathrm{N}$ controls resulted in soil nitrogen balances of $-78.9 \mathrm{~kg} \mathrm{~N} \mathrm{ha}^{-1}$ and $-47.4 \mathrm{~kg} \mathrm{~N} \mathrm{ha}^{-1}$, respectively whereas soil nitrogen balance for inoculated faba bean ranged from -9.2 to $-39.8 \mathrm{k} \mathrm{N} \mathrm{ha}^{-1}$ when both grain and haulm were removed (Figure 4). 


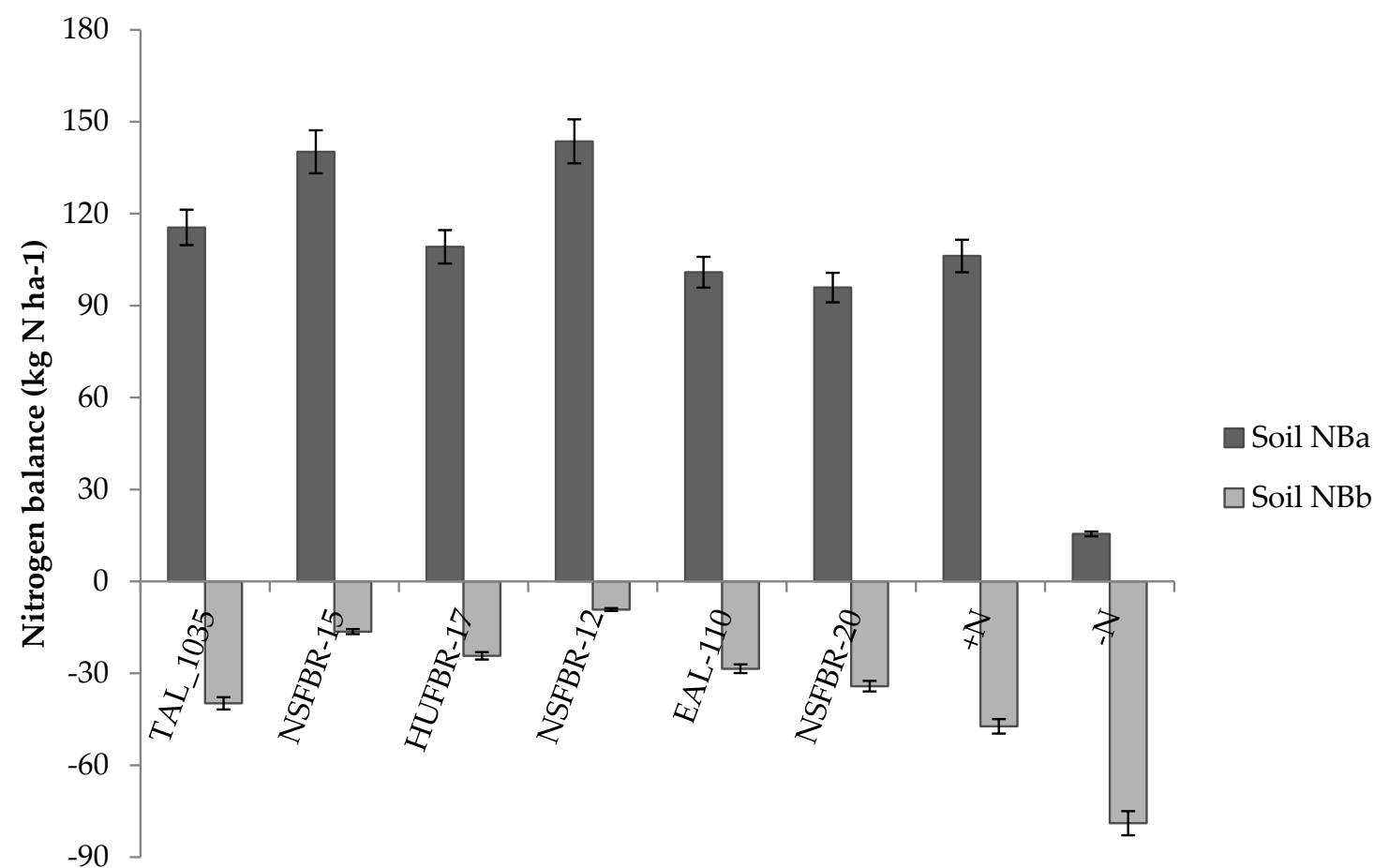

Treatment

Figure 4. Soil nitrogen balance as influenced by rhizobium strain inoculation. NBa = soil nitrogen balance if only grain is removed; $\mathrm{NBb}=$ soil nitrogen balance if both grain and haulm are removed.

\subsection{Correlation among Nodulation, Nitrogen Fixation and Nutrient Uptake}

Nodulation, nitrogen fixation, phosphorus and nitrogen uptake showed varying degrees of association (Table 6). Nodule dry weight plant $^{-1}$ was significantly and positively correlated with nitrogen fixation (0.87). Seventy-five percent of the total variation in fixed nitrogen of faba bean was explained by nodule dry weight plant ${ }^{-1}$. Nitrogen fixation was positively correlated with nitrogen and phosphorus uptake with $\mathrm{R}^{2}$ values of 0.74 and 0.65 , respectively. Increased nitrogen fixation resulted in greater nitrogen uptake. Nodulation and nitrogen fixation values had highly significant correlation with soil nitrogen balance (Table 6). Ninety percent of the total increment in soil nitrogen balance of faba bean could be attributed to increment in nitrogen fixation due to rhizobium strain inoculation. Total phosphorus uptake was strongly and positively correlated with total nitrogen uptake $\left(R^{2}=0.92\right)$ (Table 6).

Table 6. Correlation between nodule dry weight and nitrogen fixation and soil nitrogen balance if only grain was removed and nitrogen and phosphorus uptake.

\begin{tabular}{lcccccccc}
\hline \multirow{2}{*}{ Variables } & \multicolumn{2}{c}{ N-Uptake } & \multicolumn{2}{c}{ P-Uptake } & \multicolumn{2}{c}{ SNB } & \multicolumn{2}{c}{ NF } \\
\cline { 2 - 9 } & $\mathbf{r}$ & $\mathbf{R}^{\mathbf{2}}$ & $\mathbf{r}$ & $\mathbf{R}^{\mathbf{2}}$ & $\mathbf{r}$ & $\mathbf{R}^{\mathbf{2}}$ & $\mathbf{r}$ & $\mathbf{R}^{\mathbf{2}}$ \\
\hline NDW & $0.77^{* *}$ & 0.59 & $0.79^{* *}$ & 0.62 & $0.73^{* *}$ & 0.53 & $0.87^{* *}$ & 0.75 \\
NF & $0.86^{* *}$ & 0.74 & $0.81^{* *}$ & 0.65 & $0.95^{* *}$ & 0.90 & - & - \\
P-uptake & $0.96^{* *}$ & 0.92 & - & - & - & - & - & - \\
\hline
\end{tabular}

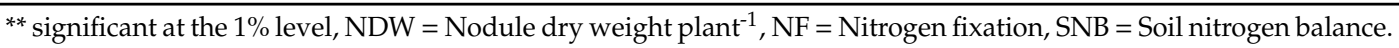

\section{Discussion}

\subsection{Inoculation Effect on Nodulation}

Nodulation responses to inoculation were observed at all the study locations. Similarly, Solomon et al. [31] reported nodulation responses from inoculation in soybean (Glycine max L. 
Mearr.) in the country. This result is also consistent with the finding of Farid and Navabi [32], who reported significant interaction of host genotype with rhizobia strain and location on symbiotic traits of common bean (Phaseolus vulgaris L.) Voisin et al. [33] revealed that the increase in nodule dry weight was associated with enhanced symbiotic efficiency during nodule growth. According to Graham et al. [34], reported that nodule dry weight is a good indicator for symbiotic efficiency and thus an important tool in strain evaluation. The results of this study elucidate the elevated affinity and greater competitiveness of strains TAL_1035 and NSFBR-15 over other strains tested.

\subsection{Inoculation Effects on Nutrient Uptake}

Rhizobium strain inoculation resulted in a significant $(p \leq 0.05)$ increase in nitrogen uptake as compared to the non-inoculated $-\mathrm{N}$ control. This result corroborates earlier reports that inoculating grain legumes with rhizobia increased nitrogen uptake [35,36]. Contrarily, Aliyu et al. [37] reported that nitrogen uptake by legumes inoculated with indigenous soil rhizobia surpassed those of inoculated treatments whereas Aziz et al. [38] observed failure of inoculation to increase nodulation and nitrogen fixation in soybean. However, our study has revealed that the introduced rhizobium strain can be highly competitive and more effective than the indigenous rhizobia.

The increase in nitrogen uptake in faba bean may be attributed to increased nitrogen fixation [39]. Rhizobia have a constructive influence on soil nutrients and thus can improve nutrient uptake [40]. Nitrogen uptake in faba bean was not significantly $(p \leq 0.05)$ affected by variety and strain interaction. The lack of significant difference in nitrogen uptake among the faba bean varieties suggests that the tested varieties had similar efficiency in nitrogen uptake.

Inoculation with NSFBR-15, TAL_1035 and NSFBR-12 resulted in the first, second and third highest total nitrogen uptake, respectively. The higher nitrogen uptake of the plants inoculated with these strains may be associated with their higher nitrogen fixing abilities. Regar et al. [41] reported that rhizobium strain inoculation increased nitrogen uptake in soybean due to enhanced nutrient availability.

Inoculation with the rhizobium strains significantly $(p \leq 0.05)$ influenced root, haulm and grain nitrogen uptake relative to non-inoculated $-\mathrm{N}$ control. The increase in haulm nitrogen uptake of inoculated faba bean was mainly due to the significant increase in nodulation, resulting in higher accumulation of nitrogen from symbiotic $\mathrm{N}_{2}$ fixation. Nitrogen is a chief component of amino acids, the building blocks of protein. Thus, increased nitrogen uptake can enhance nutritional value of the crop by increasing its protein content [42]. Khogali et al. [43] reported that enhanced nitrogen uptake can improve the crude protein and crude fiber content of fodders and can consequently improve animal nutrition.

The variation in grain nitrogen uptake is attributable to the differences in effectiveness among rhizobium strains in nitrogen fixation. The higher nitrogen uptake with TAL_1035 and NSFBR-15 inoculation coupled with the relatively lower grain nitrogen concentration (\%) suggests that all the additional nitrogen absorbed was partitioned to grain dry matter production. The higher nitrogen uptake with lower tissue nitrogen concentration explains higher nitrogen use efficiency for biomass production [44]. Neugschwandtner et al. [45] reported higher grain nitrogen concentration in faba bean variety growing under nitrogen-limiting conditions. This finding indicated that higher nitrogen concentration in grain is attributable to lower nitrogen use efficiency of faba bean. Pleijel et al. [46] explained that the primary cause for inverse relation between grain yield and grain nitrogen content is the dilution of protein by non-nitrogen compounds. In support of this conclusion, Cox et al. [47] earlier stated that increase in grain yield due to increased carbohydrate deposition through photosynthesis has a dilution effect on grain nitrogen concentration. Thus, the increase in shoot and root nitrogen uptakes following inoculation while the concentration of nitrogen $(\% \mathrm{~N})$ in these tissues remained similar to that found in control plants suggests that the additional nitrogen absorbed was used for more carbohydrate production. 
Nitrogen uptake of faba bean varied significantly $(p \leq 0.05)$ among the study locations, which reflected the effects of edaphic conditions on uptake. The higher nitrogen uptake was observed under all treatments at Hankomolicha followed by Gike Atoye. Chemical characteristics of the soils showed that N, Ca, CEC and carbon status at Gike-Atoye were relatively higher than that of the other study locations. Nyoki and Ndakidemi [48] revealed that mineral nutrient deficiencies limit legume nitrogen fixation and nutrient uptake. The soil of Hankomolicha had the highest available phosphorus content with relatively higher $\mathrm{pH}$ as compared to other locations. This implies that soil available phosphorus had an appreciable influence on nitrogen uptake. Nyoki and Ndakidemi [48] revealed that the higher the phosphorus content in soil, the higher the nitrogen fixation rate in legumes. In earlier report by Korir et al. [49], phosphorus increased nitrogen uptake by enhancing the density of rhizobia in the rhizosphere. Phosphorus stimulates plant nodule development and action of the nitrogenase enzyme in nodules of legume [50].

Inoculation of rhizobium strains appreciably enhanced phosphorus uptake in faba bean. In line with this finding, Tairo and Ndakidemi [35] reported that inoculation with Bradyrhizobium japonicum strains significantly improved phosphorus uptake in cowpea (Vignaunguiculata (L.) Walp). Increased phosphorus uptake might be attributed to indirect effects of inoculation that result in increased plant growth rhizosphere activities. Increased root capacity to absorb nutrients [51] and/or phosphorus mobilization by enhanced extracellular phosphatase activity [52] are the two most probable factors accountable for increased phosphorus uptake. Regar et al. [41] reported that rhizobium inoculation resulted in better root development and more nutrient availability due to enhanced plant growth in soybean. Inoculation enhances plant growth and consequently increases biological activity associated with roots of the host plant due to increased root exudation and organic matter decomposition, which in turn enhances nutrient availability [53]. Nitrogenous materials secreted from root hairs into the soil may increase rhizosphere microflora, especially phosphate dissolvers, causing more availability of phosphorus [39].

Rhizobium strain inoculation increased both nitrogen and phosphorus uptake simultaneously. The results indicated the dependent nature of phosphorus uptake on rhizobium strain inoculation as phosphorus is vital for nitrogen fixation [54]. Plants change N:P ratios in response to change in nitrogen availability $[55,56]$. Some [55-57] showed that increasing soil nitrogen availability through nitrogen fertilization increase N:P ratio in plant. However, the current study shows that efficient rhizobium strain inoculation and nitrogen fertilization caused relatively more increment in phosphorus uptake than nitrogen uptake. The higher increase in phosphorus uptake relative to nitrogen uptake due to inoculation support the hypothesis that nitrogen fixation requires extra phosphorus, because the process of biological nitrogen fixation is energetically costly [58]. Phosphorus uptake might therefore be probably influenced by increased nodulation, which places greater demand for phosphorus to maintain nodule tissue and plant growth as well as fix atmospheric nitrogen [59].

Phosphorus uptake in faba bean showed significant $(p \leq 0.05)$ differences among study locations due to variations in soil available phosphorus content and $\mathrm{pH}$. The soil of Hankomolicha had the highest available phosphorus content whereas that of Abala Gase had the least and relatively higher acidic soil condition. Soil acidity (low $\mathrm{pH}$ ) had significant effect on phosphorus availability to the plant due to fixation [60] and consequently decreased phosphorus uptake and efficiency of legume-rhizobia symbiosis [61].

\subsection{Inoculation Effect on Nitrogen Fixation}

Rhizobium strain inoculation enhanced $\mathrm{N}_{2}$ fixation of faba bean over the control. Contrarily, Keneni et al. [62] reported that native soil rhizobia fixed significantly higher atmospheric nitrogen than introduced rhizobium strains in northern Ethiopia. Aziz et al. [38] also reported a lack of nodulation response in soybean inoculated with a rhizobium strain. Tena et al. [63] noted that resident rhizobia in the soil usually out-compete and lessen inoculant rhizobia strains. However, rhizobium strains used in 
this study seemed more competitive and efficient in nodulation relative to native strains of rhizobia. In line with this finding, Yang et al. [64] reported significant strain effects on fixed nitrogen in soybean.

The amount of nitrogen fixed ranged from $95.6-264.7 \mathrm{~kg} \mathrm{~N} \mathrm{ha}^{-1}$, which was within the range (45-300 kg N ha ${ }^{-1}$ ) reported for faba bean [65]. The findings thus suggest that NSFBR-15 and NSFBR-12 had the highest nitrogen fixation potential as compared to the other strains tested. Nitrogen fixation was higher for the rhizobium strains, which were superior in nodulation, shoot and root dry matter production. Contrary to the finding of Yang et al. [64], this study has shown that faba bean varieties and stain $x$ variety interaction had no significant effects on nitrogen fixation. Tena et al. [63] reported similar findings on inoculated lentil (Lens culinaris) whereas Yang et al. [64] found inconsistent effects in nitrogen fixation among pea (Pisum sativum) cultivars and suggested that breeding programs focusing on grain yield should include traits of high nitrogen fixation capability to improve the environmental and economic benefits of grain legumes.

Non-inoculated $+\mathrm{N}$ faba bean plants fixed significantly higher nitrogen than non-inoculated $-\mathrm{N}$ control. Contrary to this finding, Diouf et al. [66] reported that high soil nitrogen content reduced nodulation and nitrogen fixation. They noted that a legume plant does not need symbiotic association with rhizobia where soil nitrogen is adequately available. However, the results of this study are similar to the previous findings of Youseif et al. [67] who showed that starter dose nitrogen $\left(48 \mathrm{~kg} \mathrm{~N} \mathrm{ha}^{-1}\right)$ application enhanced nodulation and nitrogen fixation of different legume crops. The increase in soil-available nitrogen generally brings about a positive influence on plant growth. The decreasing effect of nitrogen fixation that may be caused by the increase in soil mineral nitrogen may be offset by increased nitrogen requirements of plants. Vigorous crop growth increased nitrogen demand, which in turn increased nitrogen uptake and reduced soil nitrogen concentration [68].

The amount of nitrogen fixed can be estimated based on the relative reliance of the plant on nitrogen fixation (proportion of nitrogen derived from atmospheric nitrogen) and the total amount of nitrogen uptake over a growing season [69]. Variation among rhizobium strains in nitrogen fixation highlights the need for selection of effective strains for inoculant development in faba bean production. Being among the most efficient biological nitrogen fixers, faba bean can satisfy its total nitrogen need through symbiotic nitrogen fixation [70,71] provided that all conditions are favorable. The findings of this study showed that fixed nitrogen accounts for $49.1 \%-87.7 \%$ of nitrogen uptake in the faba bean. Faba bean inoculated with NSFBR-12 and NSFBR-15 fulfilled $87.7 \%$ and $85.5 \%$ of total nitrogen uptake through nitrogen fixation, respectively. However, non-inoculated faba bean plants fulfilled more of their nitrogen uptake through nitrogen derived from the soil. This finding clearly shows symbiotic nitrogen fixation was the main source of nitrogen for inoculated faba bean plants. Contrary to the findings of Asad et al. [72] on common bean, this study demonstrates that effective rhizobium strain inoculation increased total nitrogen uptake of faba bean relative to nitrogen fertilizer $\left(46 \mathrm{~kg} \mathrm{~N} \mathrm{ha}^{-1}\right)$ application. The use of effective rhizobium strains in faba bean production can thus minimize the requirement of chemical fertilizers and consequently reduces its adverse environmental effects.

\subsection{Effect of Inoculation on Soil Nitrogen Balance}

Soil nitrogen balance ranged from $15.5-143.6 \mathrm{~kg} \mathrm{~N} \mathrm{ha}^{-1}$ when only grain was removed. The net nitrogen contributed by faba bean in this study was above the range $\left(12-52 \mathrm{~kg} \mathrm{~N} \mathrm{ha}^{-1}\right)$ reported by Habtemichial et al. [73] in northern Ethiopia when only grain was exported. However, nitrogen fixed was probably under estimated in their study because of the exclusion of the belowground parts. This study, however, included root nitrogen uptake when nitrogen fixation was estimated. Below-ground dry matter has significant contribution to soil nitrogen balance [68].

Faba bean inoculated with rhizobium strains fixed more nitrogen and consequently contributed more nitrogen to the soil nitrogen balance than non-inoculated control. The lowest soil nitrogen balance in the non-inoculated $-\mathrm{N}$ control may be due to the fact that faba bean relied more on soil nitrogen for growth because of inefficient nitrogen fixation by native rhizobia. Therefore, inoculation with efficient rhizobium strains can benefit farmers through increased soil nitrogen balance and yield 
of faba bean [67]. The performance of faba bean $\left(\mathrm{N}_{2}\right.$-fixation and soil nitrogen balance) inoculated with different rhizobium strains across the study locations clearly indicates that there was the need to identify specific faba bean variety-rhizobium strain combination to specific environmental conditions for maximum economic and ecological benefits.

Soil nitrogen mining following removal of grain and haulm was more pronounced for non-inoculated $-\mathrm{N}$ control as the plant fixed lower nitrogen and removed more proportion of its nitrogen requirement from the soil. Aboveground plant residue (haulm) should be retained in the field to counterbalance soil nitrogen mining. The root and haulm of faba bean contributed 58.9-62.4\% to total plant nitrogen uptake, which could be returned into soil when only grain was exported. Legume residues generally have lower $\mathrm{C}: \mathrm{N}$ ratio compared to that of cereals which facilitate nitrogen mineralization [29]. Thus, residues of faba bean are likely to be mineralized rapidly to provide nitrogen for succeeding crop. Addition of residues can improve soil structure, microbial activities and biomass and quantity of mineralized nitrogen to benefit the following non-fixing crops in a cropping system [74]. However, there is a trade-off between the use of grain legume residues for cattle feed and for soil fertility improvement. Frank et al. [75] stated that the succeeding crops can benefit if animal manure is supplied to the field while using residues as a livestock feed. This seems an attractive alternative to conserve soil residues and associated benefits in the fields [76].

Rhizobium strains NSFBR-15 and NSFBR-12 emerged as effective and the most promising strains for enhancing nitrogen fixation, soil nitrogen balance and nutrient uptake at the study locations. The performance of NSFBR-15 and NSFBR-12 were consistently higher under field conditions. The previous findings of Argaw [77] also showed that NSFBR-15 and NSFBR-12 were the most efficient strains among 49 indigenous faba bean nodulating rhizobium strains tested under greenhouse conditions. Symbiotic effectiveness of rhizobium strains is variable $[77,78]$ and their efficiency depends on the interaction among plant genotype, rhizobium strain and the environment [79].

\subsection{Correlation among Nodulation, Nitrogen Fixation and Nutrient Uptake}

Results of correlation analysis showed significant $(p \leq 0.01)$ positive relationship between nodule dry weight and nitrogen uptake of faba bean. This was in line with the findings of Delić et al. [80] who reported a positive correlation between nodulation and nitrogen fixation in adzuki bean (Vigna angularis). The amount of nitrogen fixed was also positively correlated with nitrogen uptake. These findings indicate that increased nitrogen fixation due to inoculation further enhanced nitrogen uptake of faba bean suggesting the use of nodulation and nitrogen uptake as indicators of nitrogen fixation potential of rhizobia strains [81]. Ruiz-Diez et al. [82] demonstrated that plant nitrogen uptake was the most suitable parameter that can be used to select highly effective and competitive rhizobium strains.

The correlation results showed that $75 \%$ of the total variation in nitrogen fixation of faba bean was explained by nodule dry weight plant ${ }^{-1}$. Agreeing with the findings of Kantar et al. [83] and Ogutcu et al. [84], the results herein demonstrate that increased nodule dry weight due to rhizobium strain inoculation is an efficient way to boost nitrogen fixation in faba bean. Rhizobium strain inoculation triggered the formation of more nodules to fix more nitrogen. Therefore, effectiveness in nitrogen fixation and competitiveness for nodulation should both be considered during rhizobium strain selection to improve faba bean production. This is because nodulation is not always positively correlated with fixed nitrogen as nodules have different nitrogenase activity, which could lead to high nitrogen fixation with low nodulation $[64,85]$.

Phosphorus uptake greatly contributed $\left(\mathrm{R}^{2}=0.92\right)$ to the variation in nitrogen uptake of faba bean. Similarly, Mweetwa et al. [86] reported that phosphorus uptake contributed to $97 \%$ of the variation in nitrogen uptake of chickpea. Ye et al. [87] and Belanger et al. [57] observed that an increase in nitrogen fixation resulted in increased phosphorus uptake. This observation might be attributed to indirect effects of rhizobia strain inoculation that causes increased capacity of roots to absorb more nutrients [51] and stimulate phosphorus mobilization through enhanced extracellular phosphatase activity [52]. Phosphorus uptake was positively correlated $\left(R^{2}=0.65\right)$ to the amount of nitrogen fixed 
indicating that nitrogen fixation was highly dependent on soil phosphorus. Thus, its deficiency directly influences nitrogen fixation in legume plant. This relationship is worth establishing because of the role of phosphorus in nodulation, nodule functioning, and, consequently, nitrogen fixation and uptake.

\section{Conclusions}

Rhizobium strain inoculation enhanced nitrogen fixation, soil nitrogen balance, nitrogen uptake and phosphorus uptake of faba bean. Inoculation with competitive and effective rhizobium strains is necessary to achieve maximum nitrogen fixation and soil nitrogen balance. Rhizobium strains NSFBR-15 and NSFBR-12 emerged as the most promising and effective strains for nitrogen fixation, soil nitrogen balance and nutrient uptake under field conditions.

Author Contributions: Conceptualization, B.B.A. and N.E.-M.; methodology, B.B.A., V.L. and N.E.-M.; formal analysis, B.B.A.; investigation, B.B.A.; data collection, B.B.A.; writing-original draft preparation, B.B.A.; writing-review and editing, B.B.A.; validation, V.L. and N.E.-M.; editing and supervision, V.L. and N.E.-M. All authors have read and agreed to the published version of the manuscript.

Funding: This research was funded by the institutional collaboration project of Hawassa University and NMBU, supported by the government of Norway.

Acknowledgments: Hawassa University (Norad Project) and International Plant Nutrition Institutes (IPNI) are gratefully acknowledged for financial support.

Conflicts of Interest: I hereby declare that there are no potential conflicts of institutional, professional and financial interests that may be perceived to influence the results and discussion reports in this paper. I have full access to all the study data, take full responsibility for the accuracy of the data analysis, and have authority over manuscript preparation and decisions to submit the manuscript for publication. The funders had no role in the design of the study; in the collection, analyses, or interpretation of data; in the writing of the manuscript, or in the decision to publish the results.

\section{References}

1. Smaling, E.M.A.; Stoorvogel, J.J.; Windmeijer, P.N. Calculating soil nutrient balances in Africa at different scales: II district scale. Fertil. Res. 1993, 35, 237-250. [CrossRef]

2. Ladha, J.K.; Padre, A.T.; Punzalan, G.C.; Castillo, E.; Singh, U.; Reddy, C.K. Non destructive estimation of shoot nitrogen in different rice genotypes. Agron. J. 1998, 90, 33-40. [CrossRef]

3. Siczek, A.; Lipiec, J. Impact of faba bean seed rhizobial inoculation on microbial activity in the rhizosphere soil during growing season. Int. J. Mol. Sci. 2016, 17, 784. [CrossRef] [PubMed]

4. Jensen, E.S.; Hauggard-Nielsen, H. How can increased use of biological $\mathrm{N}_{2}$ fixation in agriculture benefit the environment? Plant Soil 2003, 252, 177-186. [CrossRef]

5. Htwe, A.Z.; Moh, S.M.; Soe, K.M.; Moe, K.; Yamakawa, T. Effects of biofertilizer produced from Bradyrhizobium and Streptomyces griseoflavus on plant, growth, nodulation, nitrogen fixation, nutrient uptake, and seed yield of mung bean, cowpea and soybean. Agronomy 2019, 9, 77. [CrossRef]

6. Laguerre, G.; Louvrier, P.; Allard, M.R.; Amarger, N. Compatibility of rhizobial genotypes within natural populations of Rhizobium leguminosarum biovar viciae for Nodulation of Host Legumes. Appl. Environ. Microbiol. 2003, 69, 2276-2283. [CrossRef]

7. Mutch, L.A.; Young, J.P.W. Diversity and specificity of Rhizobium leguminosarum boivar viciae on wild and cultivated legumes. Mol. Ecol. 2004, 13, 2435-2444. [CrossRef]

8. Laguerre, G.; Depret, G.; Bourion, V.; Duc, G. Rhizobium leguminosarum biovar viciae genotypes interact with pea plants in developmental responses of nodules, roots and shoots. New Phytol. 2007, 176, 680-690. [CrossRef]

9. Sachs, J.L.; Kembel, S.W.; Lau, A.M.; Simms, E.L. In situphylogenetic structure and diversity of wild Bradyrhizobium communities. Appl. Environ. Microbiol. 2009, 75, 4727-4735. [CrossRef]

10. Sánchez-Cañizares, C.; Jorrín, B.; Durán, D.; Nadendla, S.; Albareda, M.; Rubio-Sanz, L.; Lanza, M.; González-Guerrero, M.; Prieto, R.I.; Brito, B.; et al. Genomic diversity in the endosymbiotic bacterium Rhizobium leguminosarum. Genes 2018, 9, 60. [CrossRef]

11. McKenzie, R.H.; Middleton, A.B.; Solberg, E.D.; De-Mulder, J.; Flore, N.; Clayton, G.W. Response of peat or rhizobia inoculation and start nitrogen in Alberta. Can. J. Plant Sci. 2001, 81, 637-643. [CrossRef] 
12. Downie, J.A. The roles of extracellular proteins, polysaccharides and signals in the interactions of rhizobia with legume roots. FEMS Microbiol. Rev. 2010, 34, 150-170. [CrossRef] [PubMed]

13. Sachs, J.L.; Ehinger, M.O.; Simms, E.L. Origins of cheating and loss of symbiosis in wild Bradyrhizobium. J. Evol. Biol. 2010, 23, 1075-1089. [CrossRef] [PubMed]

14. Fujita, H.; Aoki, S.; Kawaguchi, M. Evolutionary dynamics of nitrogen fixation in the legume-rhizobia symbiosis. PLoS ONE 2014, 9, e3670. [CrossRef] [PubMed]

15. Beltayef, H.; Melki, M.; Saidi, W.; Samaali, S.; Muscolo, A.; Cruz, C.; Garoui, T. Statement of biological nitrogen fixation in snap bean under mediterranean semi-arid conditions. Bulg. J. Agric. Sci. 2018, 24, 244-251.

16. Stajković, O.; Delić, D.; Jošić, D.; Kuzmanović, D.; Rasulić, N.; Knežević-Vukčević, J. Improvement of common bean growth by co-innoculation with Rhizobium and plant growth-promoting bacteria. Rom. Biotechnol. Lett. 2011, 16, 5919-5926.

17. Bouyoucos, G.J. Hydrometer method improvement for making particle size analysis of soils. Agron. J. 1962, 54, 179-186. [CrossRef]

18. Black, G.R.; Hertge, K.H. Bulk density. In Methods of Soil Analysis; Klute, A., Ed.; SSSA: Madison, WI, USA, 1986; pp. 377-382.

19. Carter, M.R.; Gregorich, E.G. Canadian Soil Science Society. In Soil Sampling and Methods of Analysis, 2nd ed.; CRC Press: Boca Raton, FL, USA, 2008.

20. Mclean, E.O. Aluminum. In Methods of Soil Analysis; Part 2 chemical methods; Black, C.A., Ed.; America Sci. Agron.: Madison, WI, USA, 1965; pp. 978-998.

21. Van Reeuwijk, L.P. Technical paper/international soil reference and information center. In Procedures for Soil Analysis, 6th ed.; Scientific Research: Wageningen, The Netherlands, 2002.

22. Walkley, A.; Black, I.A. An examination of the Degtjareff method for determining soil organic matter and a proposed modification of the chromic acid titration method. Soil Sci. 1934, 37, 29-38. [CrossRef]

23. Bremner, J.M.; Mulvaney, C.S. Nitrogen total. In Methods of Soil Analysis, Part 2, Chemical And Microbiological Properties; Page, A.L., Ed.; SSSA: Madison, Wiscosin, 1982; pp. 595-622.

24. Olsen, S.R.; Cole, C.V.; Watanabe, F.S.; Dea, L.A. Estimation of Available Phosphorous in Soils by Extraction with Sodium Bicarbonate; USDA: Washington, DC, USA, 1954; Volume 939, pp. 1-19.

25. Rice, W.A.; Clyton, G.W.; Lupwayi, N.Z.; Olsen, P.E. Evaluation of coated seeds as a rhizobium delivery system for field pea. Can. J. Plant Sci. 2001, 81, 248-249. [CrossRef]

26. AOAC (Association of Official Analytical Chemists). Official Methods of Analysis, 6th ed.; AOAC: Washington, DC, USA, 1995.

27. NSL. Manual for Plant Analysis and Interpretation; Food and Agriculture Organization of the United Nations: Addis Ababa, Ethiopia, 1994.

28. Unkovich, M.J.; Herridge, D.; Peoples, M.; Cadisch, G.; Boddey, R.; Giller, K.; Alves, B.; Chalk, P. Measuring Plant-Associated Nitrogen Fixation in Agricultural Systems; ACIAR Monography: Canberra, Australia, 2008; Volume 136, p. 258.

29. Kermaha, M.; Frankeb, A.C.; Adjei-Nsiahc, S.; Adjei-Nsiahc, S.; Ahiabord, B.D.K.; Abaidoo, R.C.; Giller, K.E. $\mathrm{N}_{2}$-fixation and $\mathrm{N}$ contribution by grain legumes under different soil fertility status and cropping systems in the Guinea savanna of northern Ghana. Agric. Ecosyst. Environ. 2018, 261, 201-210. [CrossRef]

30. SAS. SAS/STAT Software Syntax; Version 9.0; SAS Institute: Cary, NC, USA, 2010.

31. Solomon, T.; Pant, L.M.; Angaw, T. Effects of inoculation by Bradyrhizobium japonicum strains on nodulation, nitrogen fixation, and yield of soybean (Glycine max L. Merill) varieties on Nitosols of Bako, western Ethiopia. Int. Sch. Res. Netw. ISRN Agron. 2012, 2012. [CrossRef]

32. Farid, M.; Navabi, A. $\mathrm{N}_{2}$ fixation ability of different dry bean genotypes. Can. J. Plant Sci. 2015, 95, $1243-1257$. [CrossRef]

33. Voisin, A.S.; Salon, C.; Warembourg, F.R. Seasonal patterns of $13 \mathrm{C}$ partitioning between shoot and nodulated roots of $\mathrm{N}_{2}$ - or nitrate-fed Pisum sativum (L.). Ann. Bot. 2003, 91, 539-546. [CrossRef] [PubMed]

34. Graham, P.H.; Hungria, M.; Tlusty, B. Breeding for better nitrogen fixation in grain legumes: Where do the rhizobia fit in? Crop Manag. 2004. [CrossRef]

35. Tairo, E.V.; Ndakidemi, P.A. Micronutrients' uptake in soybean (Glycine max L.) as affected by Bradyrhizobium japonicum inoculation and phosphorus (P.) supplements. World J. Soil Crop Sci. Res. 2014, 1, 1-9. 
36. Zoundji, C.C.; Houngnandan, P.; Amidou, M.H.; Kouelo, F.A.; Toukourou, F. Inoculation and phosphorus application effects on soybean (Glycine max L. Merrill) productivity grown in farmers' fields of Benin. J. Anim. Plant Sci. 2015, 25, 1384-1392.

37. Aliyu, I.M.; Yusuf, A.A.; Abaidoo, R.C. Response of grain legumes to rhizobial inoculation in two savanna soils of Nigeria. Afr. J. Microbiol. Res. 2013, 7, 1332-1342.

38. Aziz, A.L.; Ahiabor, B.D.K.; Opoku, A.; Abaidoo, R.C. Contribution of rhizobium inoculants and phosphorus fertilizer to biological nitrogen fixation, growth and grain yield of three soybean varieties on a Fluvic Luvisol. Am. J. Exp. Agric. 2016, 10, 1-11. [CrossRef]

39. Talaat, N.B.; Abdallah, A.M. Response of faba bean (Vicia faba L.) to dual inoculation with Rhizobium and VA mycorrhiza under different levels of $\mathrm{N}$ and P fertilization. J. Appl. Sci. Res. 2008, 4, 1092-1102.

40. Lugtenberg, B.; Kamilova, F. Plant-growth-proming rhizobacteria. Annu. Rev. Microbiol. 2009, 63, 541-556. [CrossRef]

41. Regar, M.K.; Meena, R.H.; Jat, G.; Mundra, S.L. Effect of different rhizobial strains on growth and yield of soybean (Glycine max L. Merrill). Int. J. Curr. Microbiol. App. Sci. 2017, 6, 3653-3659. [CrossRef]

42. Gasim, S.; Hamad, S.A.A.; Abdelmula, A.; Ahmed, I.A.M. Yield and quality attributes of faba bean inbred lines grown under marginal environmental condition of Sudan. Food Sci. Nutr. 2015, 3, 539-547. [CrossRef] [PubMed]

43. Khogali, M.E.; Dagash, Y.M.I.; EL-Hag, M.G. Nitrogen fertilizer effects on quality of fodder beet (Beta vulgaris var. Crassa). Agric. Biol. J. N. Am. 2011, 292, 270-278. [CrossRef]

44. Araujo, A.P.; Teixeira, M.G. Relationship between grain yield and accumulation of biomass, nitrogen and phosphorus in common bean cultivars. Revista Brasileira de Ciência do Solo 2008, 32, 1977-1986. [CrossRef]

45. Neugschwandtner, R.; Ziegler, K.; Kriegner, S.; Wagentristl, H.; Kaul, H.P. Nitrogen yield and nitrogen fixation of winter faba Beans. Acta Agric. Scand. Sect. B Soil Plant Sci. 2015, 65, 658-666. Available online: http://www.tandfonline.com/loi/sagb20 (accessed on 25 January 2018). [CrossRef]

46. Pleijel, H.; Mortensen, L.; Fuhrer, J.; Ojanpera, K.; Danielsson, H. Grain protein accumulation in relation to grain yield of spring wheat (Triticum eastivum L.) grown in open-top chambers with different concentrations of ozone, carbon dioxide and water availability. Agric. Ecosyst. Environ. 1999, 72, 265-270. [CrossRef]

47. Cox, M.C.; Qualset, C.O.; Rains, D.W. Genetic variation for nitrogen assimilation and translocation in wheat. III. Nitrogen translocation in relation to grain yield protein. Crop Sci. 1986, 26, 737-740. [CrossRef]

48. Nyoki, D.; Ndakidemi, P.A. Effects of Bradyrhizobium japonicum inoculation and supplementation with phosphorus on macronutrients uptake in cowpea (Vigna unguiculata L. Walp). Am. J. Plant Sci. 2014, 5, 442-451. [CrossRef]

49. Korir, H.; Mungal, N.W.; Thuita, M.; Hamba, Y.; Masso, C. Co-inoculation effect of rhizobia and plant growth promoting rhizobacteria on common bean in a low phosphorus soil. Front. Plant Sci. 2017, 8, 141. [CrossRef]

50. Israel, D.W. Symbiotic dinitrogen fixation and host-plant growth during development of and recovery from phosphorus deficiency. Physiol. Plant. 1993, 88, 294-300. [CrossRef]

51. Ziadi, N.; Be'langer, G.; Cambouris, A.N.; Tremblay, N.; Nolin, M.C. Relationship between P and N concentrations in corn. Agron. J. 2007, 199, 833-841. [CrossRef]

52. Agren, G.I.; Wetterstedt, M.J.Å.; Billberger, M.F.K. Nutrient limitation on terrestrial plant growth-modeling the interaction between nitrogen and phosphorus. New Phytol. 2012, 194, 153-960. [CrossRef]

53. Ball, B.C.; Crichton, I.; Horgan, G.W. Dynamics of upward and downward $\mathrm{N}_{2} \mathrm{O}$ and $\mathrm{CO}_{2}$ fluxes in ploughed and no-tilled soils in relation to water-filled pore space, compaction and crop presence. Soil Tillage Res. 2008, 101, 20-30. [CrossRef]

54. Tahir, M.M.; Abbasi, M.K.; Rahim, N.; Khaliq, A.; Kazmi, M.H. Effect of Rhizobium inoculation and NP fertilization on growth, yield and nodulation of soybean (Glycine max L.) in sub-humid hilly region of Rawa Lakot, Azud Jammu and Kashmir, Pakistan. Afr. J. Biotechnol. 2009, 8, 6191-6200.

55. Sardans, J.; Rivas-Ubach, A.; Uelas, J.P. The C:N:P stoichiometry of organisms and ecosystems in a changing world: A review and perspectives. Perspect. Plant Ecol. Evol. Syst. 2012, 14, 33-47. [CrossRef]

56. Lu, X.T.; Kong, D.L.; Pan, Q.M.; Simmons, M.E.; Han, X.G. Nitrogen and water availability interact to affect leaf stoichiometry in semi-arid grassland. Oecologia 2012, 168, 301-310. [CrossRef]

57. Belanger, G.; Claessens, A.; Ziadi, N. Grain nitrogen and phosphorus relationships in maize. Field Crops Res. 2012, 126, 1-7. [CrossRef] 
58. Taylor, B.N.; Menge, D.N.L. Light regulates tropical symbiotic nitrogen fixation more strongly than soil nitrogen. Nat. Plants 2018, 4, 655-661. [CrossRef]

59. Reem, M.H. The effect of phosphorus in nitrogen fixation in legumes. Agric. Res. Technol. Access J. 2017, 5, 555652. [CrossRef]

60. Raven, J.A. Protein turnover and plant RNA and phosphorus requirement in relation to nitrogen fixation. Plant Sci. 2012, 189, 25-35. [CrossRef]

61. Bello, S.K.; Yusuf, A.A.; Cargele, M. Performance of cowpea as influenced by native strain of rhizobia, lime and phosphorus in Samaru, Nigeria. Symbiosis 2018, 75, 167-176. [CrossRef] [PubMed]

62. Keneni, A.; Feten, A.; Prabu, P.C. Characterization of acid and salt tolerant rhizobial strains isolated from faba bean fields of Wollo, northern Ethiopia. J. Agric. Sci. Technol. 2010, 2, 365-376.

63. Tena, W.; Wolde-Meskel, E.; Walley, F. Symbiotic efficiency of native and exotic Rhizobium strains nodulating lentil (Lens culinaris Medik.) in soils of southern Ethiopia. Agronomy 2016, 6, 11. [CrossRef]

64. Yang, Y.; Zhao, Q.; Li, X.; Ai, W.; Liu, D.; Qi, W.; Zhang, M.; Yang, C.; Liao, H. Characterization of genetic basis on synergistic interactions between root architecture and biological nitrogen fixation in soybean. Front. Plant Sci. 2017, 8, 1466. [CrossRef]

65. Smil, V. Nitrogen in crop production: An account of global flows. Glob. Biogeochem. Cycles 1999, 13, 647-662. [CrossRef]

66. Diouf, A.; Diop, T.A.; Gueye, M. Nodulation in situ of common bean (Phaseolus vulgaris L.) and field outcome of an elite symbiotic association in Senegal. Res. J. Agric. Biol. Sci. 2008, 4, 810-818.

67. Youseif, S.H.; Fayrouz, H.; El-Megeed, F.H.A.; Sahel, S.A. Improvement of faba bean yield using Rhizobium/Agrobacterium inoculant in low fertility sandy soil. Agronomy 2017, 7, 2. [CrossRef]

68. Peoples, M.B.; Brockwell, J.; Herridge, D.F.; Rochester, I.J.; Alves, B.J.R.; Urquiaga, S.; Boddey, R.M.; Dakora, F.D.; Bhattarai, S.; Maskey, S.L.; et al. The contributions of nitrogen-fixing crop legumes to the productivity of agricultural systems. Symbiosis 2009, 48, 1-17. [CrossRef]

69. Jensen, E.S.; Peoples, M.B.; Hauggaard-Nielsen, H. Faba bean in cropping systems. Field Crops Res. 2010, 115, 203-216. [CrossRef]

70. Herridge, D.F.; Peoples, M.B.; Boddey, R.M. Global inputs of biological nitrogen fixation in agricultural systems. Plant Soil 2008, 311, 1-18. [CrossRef]

71. Lindemann, W.C.; Glover, C.R. Nitrogen Fixation by Legumes; Cooperative Extension Service, College of Agriculture and Home Economics New Mexico State University: New Mexico, NM, USA, 2003; pp. 1-4.

72. Asad, S.; Malik, K.A.; Hafeez, F.Y. Competition between inoculated and indigenous Rhizobium/Bradyrhizobium spp. strains for nodulation of grain and fodder legumes in Pakistan. Biol. Fertil. Soils 1991, 12, 107-111. [CrossRef]

73. Habtemichial, K.H.; Singh, B.R.; Aune, J.B. Wheat response to $\mathrm{N}_{2}$ fixed by faba bean (Vicia faba L.) as affected by sulfur fertilization and rhizobial inoculation in semi-arid northern Ethiopia. J. Plant Nutr. Soil Sci. 2007, 170, 412-418. [CrossRef]

74. Whalen, J.K. Managing soil biota-mediated decomposition and nutrient mineralization in sustainable agroecosystems. Adv. Agric. 2014, 2014, 384604. [CrossRef]

75. Frank, A.C.; Laberge, G.; Oyewole, B.D.; Schulz, S. A comparison between legume technologies and fallow, and their effects on maize and soil traits, in two distinct environments of the West Africa savannah. Nutr. Cycl. Agroecosys 2008, 82, 117-135. [CrossRef]

76. Martin, G.; Moraine, M.; Ryschawy, J.; Magne, M.A.; Asai, M.; Sarthou, J.P.; Duru, M.; Therond, O. Crop-livestock integration beyond the farm level: A review. Agron. Sustain. Dev. 2016, 36, 53. [CrossRef]

77. Argaw, A. Characterization of symbiotic effectiveness of rhizobia Nodulating faba bean (Vicia faba L.) isolated from central Ethiopia. Res. J. Microbiol. 2012, 7, 280-296. [CrossRef]

78. Minalku, A.; Gebrekidan, H.; Assefa, F. Symbiotic effectiveness and characterization of Rhizobium strains of faba bean (Vicia faba L.) Collected from eastern and western Hararghe highlands of Ethiopia. Ethiop. J. Nat. Resour. 2009, 11, 223-244.

79. Ferreira, P.A.A.; Bomfeti, C.A.; Soares, B.L.; Moreira, F.M.S. Efficient nitrogen-fixing rhizobium strains isolated from Amazonian soils are highly tolerant to acidity and aluminum. World J. Microbiol. Biotechnol. 2012, 28, 1947-1959. [CrossRef] 
80. Delić, D.; Stajković, O.; Rasulić, N.; Kuzmanović, D.; Jošić, D.; Milićić, B. Nodulation and $\mathrm{N}_{2}$ fixation effectiveness of Bradyrhizobium strains in symbiosis with Adzuki bean. Vigna angularis. Braz. Arch. Biol. Technol. 2010, 53, 293-299.

81. Patra, R.K.; Pant, L.M.; Pardhan, K. Response of soybean to inoculation with rhizobial strains: Effect on growth, yield, N uptake and soil status. World J. Agric. Sci. 2012, 8, 51-54.

82. Ruiz-Diez, B.; Fajardo, S.; Fernández-Pascual, M. Selection of rhizobia from agronomic legumes grown in semi-arid soils to be employed as bio-inoculants. Agron. J. 2012, 104, 550-559. [CrossRef]

83. Kantar, F.; Elkoca, E.; Oğutcu, H.; Algur, Ö.F. Chickpea yields in relation to Rhizobium inoculation from wild chickpea at high altitudes. J. Agron. Crop Sci. 2003, 189, 291-297. [CrossRef]

84. Oğutcu, H.; Algur, O.F.; Elkoca, E.; Kantar, F. The determination of symbiotic effectiveness of Rhizobium strains isolated from wild chickpeas collected from high altitudes in Erzurum. Turk. J. Agric. 2008, 32, 241-248.

85. Boughribil, S.; Abumsimir, B.; Montassir, L.; Tarek, F.; Ennaji, M.M.; Bessi, H. Effect of competitiveness on nodulation and nitrogen fixation in common bean (Phaseolus vulgaris L.). J. Mater. Environ. Sci. 2018, 9, 828-833.

86. Mweetwa, M.; Chilombo, G.; Gondwe, B.M. Nodulation, nutrient uptake and yield of common bean inoculated with rhizobia and Trichoderma in an acid soil Alice. J. Agric. Sci. 2016, 8, 61-71.

87. Ye, Y.; Liang, X.; Chen, Y.; Li, L.; Ji, Y.; Zhu, C. Carbon, nitrogen and phosphorus accumulation and partitioning, and $\mathrm{C}: \mathrm{N}: \mathrm{P}$ stoichiometry in late-season rice under different water and nitrogen managements. PLoS ONE 2014, 9, e101776. [CrossRef]

(C) 2020 by the authors. Licensee MDPI, Basel, Switzerland. This article is an open access article distributed under the terms and conditions of the Creative Commons Attribution (CC BY) license (http://creativecommons.org/licenses/by/4.0/). 